\title{
Water Pollutant Discharge Indicator Estimation and Water Quality Prediction in Pak Kret District, Bangkok, Thailand
}

\author{
Yoshiaki TSUZUKI* and Thammarat KOOTTATEP** \\ *Research Center for Coastal Lagoon Environments, Shimane University, Shimane 690-8054 \\ Japan. \\ **Environment Engineering and Management, Asian Institute of Technology, Pathumthani 1210 \\ Thailand.
}

\begin{abstract}
After several decades of water and sanitation sector development in developing countries, ambient water pollution is still one of the major environmental problems. Safe and convenient sanitation, toilet use, public health issues, hygiene behavior and ambient water quality improvement are purposes and benefits of sanitation. The sanitation indicator of Millennium Development Goals (MDGs) showed that the proportion of population with access to improved sanitation in Thailand was $99 \%$ in 2004, however, ambient water quality deterioration is still a major environmental problem. Therefore, pollutant discharge and affordability should be discussed in a quantitative manner. In this paper, municipal wastewater pollutant discharge contribution to ambient water pollutant loads was given attention. The pollutant load per capita flowing into water body $\left(\mathrm{PLC}_{\mathrm{wb}}\right)$ were estimated as $7.2 \mathrm{~g}$-BOD person ${ }^{-1}$ day $^{-1}, 9.2 \mathrm{~g}^{-\mathrm{TN}}$ person $^{-1}$ day $^{-1}$ and 1.2 g-TP person $^{-1}$ day $^{-1}$, in Pak Kret Municipality, a peri-urban area of Bangkok, Thailand. $\mathrm{PLC}_{\mathrm{wb}}$ can evaluate both anthropogenic pollutant removal effects of wastewater treatment systems and natural purification effects in ambient water. Scenario-based analysis showed water quality improvement in the Chao Phraya River to be $0.12-0.26 \mathrm{mg}^{-B O D ~ l^{-1}}$,

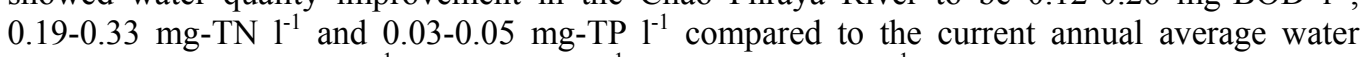
quality of $1.94 \mathrm{mg}-\mathrm{BOD} \mathrm{l}^{-1}, 1.19 \mathrm{mg}-\mathrm{TN}^{-1}$, and $0.22 \mathrm{mg}-\mathrm{TP}^{-1}$. Pollutant discharges per capita (PDCs) estimation results and cost-benefit comparison results showed the effectiveness of PDCs to evaluate various municipal wastewater treatment systems.
\end{abstract}

Keywords: municipal wastewater; pollutant discharge per capita (PDC); pollutant load per capita flowing into water body $\left(\mathrm{PLC}_{\mathrm{wb}}\right)$; water and wastewater management

\begin{abstract}
ABBREVIATIONS
BMA: Bangkok Metropolitan Area;

BOD: biological oxygen demand;

CJ: combined johkasou (an on-site treatment system in Japan);

COD: chemical oxygen demand;

CP: community plant;

EKC: environmental Kuznets curve;

IGES: Institute of Global Environmental Strategies, Japan;

IWRM: integrated water resource management;

LCA: life cycle assessment;

MDGs: Millennium Development Goals;

MFA: material flux analysis or material flow analysis;

ODA: overseas development assistance;

Address correspondence to Yoshiaki Tsuzuki, Shimane University,

E-mail: tsuzuki.yoshiaki@gmail.com

Received: November 04, 2009, Accepted: February 08, 2010.
\end{abstract}

$\mathrm{COD}_{\mathrm{Mn}}$ : chemical oxygen demand measured with manganese dioxide;

NST: night soil treatment system (an old-type on-site treatment system in Japan); 
PCD: Pollution Control Department, Thailand

PDC: pollutant discharge per capita;

PDC_BOD: BOD discharge per capita;

PDL: pollutant discharge per land area

PGC: pollutant generation per capita;

$\mathrm{PLC}_{\mathrm{wb}}$ : pollutant load per capita flowing into water body;

$\mathrm{PLC}_{\mathrm{wb}}$ BOD: BOD load per capita flowing into water body;

$\mathrm{PLC}_{\mathrm{wb}}$ TN: TN load per capita flowing into water body;

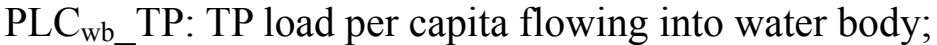

SJ: simple johkasou (an old-type on-site treatment system in Japan);

TN: total nitrogen;

TP: total phosphorus;

TSP: total suspended particle (air quality);

WEPA: Water Environment Partnership in Asia;

WWAP: United Nations (World) Water Assessment Program; and

WWTPs: wastewater treatment plants;

\section{INTRODUCTION}

Pollutant discharge and pollutant load indicators are effective to clarify the relationship between municipal wastewater pollutant discharge and ambient water quality (Tsuzuki, 2007; 2008; 2009b; Tsuzuki et al., 2008a,b; 2009). The indicators may be applicable for comparison of cost-effectiveness of wastewater treatment systems. This kind of quantitative analyses and comparisons will enhance understanding of the situations of sanitation system to assess the sustainability of sanitation systems in developing and developed countries. Ujang and Buckley (2002) summarized the distance between desirable development in developing countries and development scheme by developed country experts in water and wastewater planning and management. Thus, detailed or quantitative investigations and analyses on the actual conditions of the whole planning and management in developing countries are truly necessary.

In the Millennium Development Goals (MDGs), sanitation target is a central topic in the world water and sanitation sectors. We should consider from the historical aspects of sanitation from the International Drinking Water and Sanitation Decade to the water and sanitation goals of MDGs to find desirable directions of sanitation system development in developing countries (Table 1). Decreasing proportion of population without access to safe drinking water and appropriate municipal wastewater treatment facilities are very urgent tasks of the world community. These goals have been determined based on the discussions and considerations for a few decades starting from the United Nations Conference on Human Environment in Stockholm in 1972 (UNESCO-WWAP, 2003).

This paper focuses on municipal wastewater discharge reduction as a purpose or a benefit of sanitation. In the first edition of the World Water Report (UNESCO-WWAP, 2003), sanitation provisions were summarized as (1) safe and convenient sanitation, (2) toilet use, (3) public health issues and (4) hygiene behavior. One more step to achieve a good level of sanitation is to reduce pollutant discharges. Pollutant discharge reduction has been targeted to improve water quality in ambient water especially in developed countries. After the achievement of sanitation goal of the MDGs or even on the way to 
achieve the goal, reducing pollutant discharge should be also considered even in developing countries.

Table 1 - Discussions and considerations for a few decades in the sanitation sector (based on Choguill et al., 1993, UNESCO-WWAP, 2003, and United Nations Secretary-General's Advisory Board on Water and Sanitation, 2006)

\begin{tabular}{|c|c|c|}
\hline Year & Topic & Discription \\
\hline 1972 & $\begin{array}{l}\text { United Nations Conference on Human } \\
\text { Environment in Stockholm }\end{array}$ & $\begin{array}{l}\text { For "the discharge of toxic substances or of other substances and the release of heat", } \\
\text { "the just struggle of the peoples of ill countries against pollution should be supported." }\end{array}$ \\
\hline 1981-1990 & $\begin{array}{l}\text { International Drinking Water and Sanitation } \\
\text { Decade }\end{array}$ & $\begin{array}{l}\text { 'The goal of the Decade was that, by the end of } 1990 \text {, all people should possess adequate } \\
\text { water supply and satisfactory means of excreta and sullage disposal...it would have } \\
\text { involved the provision of water and sanitation services to over } 650,000 \text { people per day } \\
\text { for the entire ten year period'. }\end{array}$ \\
\hline 1990 & $\begin{array}{l}\text { New Delhi Statement in the Global Consultation } \\
\text { on Safe Water and Sanitation for the 1990s }\end{array}$ & $\begin{array}{l}\text { 'Some for all rather than more for some' was included and it was stated that 'safe water } \\
\text { and proper means of waste disposal.....must be at the center of integrated water } \\
\text { resources management'. }\end{array}$ \\
\hline 1994 & $\begin{array}{l}\text { Action Programme of the Ministerial Conference } \\
\text { on Drinking Water Supply and Environmental } \\
\text { Sanitation in Noordwijk }\end{array}$ & $\begin{array}{l}\text { It was declared that 'to assign high priority to programmes designed to provide basic } \\
\text { sanitation and excreta disposal systems to urban and rural areas'. }\end{array}$ \\
\hline 1995 & Copenhagen Declaration on Social Development & $\begin{array}{l}\text { 'Safe drinking water and sanitation' was included in the efforts to be addressed } \\
\text { considering the root causes of poverty. }\end{array}$ \\
\hline 1997 & $\begin{array}{l}\text { Marrakech Declaration in the First World Water } \\
\text { Forum }\end{array}$ & Accessing to clean water and sanitation was recognized as the basic human needs. \\
\hline 1998 & $\begin{array}{l}\text { Paris Declaration on Water and Sustainable } \\
\text { Development }\end{array}$ & $\begin{array}{l}\text { The importance was emphasized 'to ensure the achievement of sustainable development, } \\
\text { management and protection, and equitable use of freshwater resources'. }\end{array}$ \\
\hline 2000 & $\begin{array}{l}\text { World Water Vision in the Second Water Forum in } \\
\text { Hague }\end{array}$ & Stakeholders involvement and funding were emphasized. \\
\hline 2002 & $\begin{array}{l}\text { Implementation plan of the Johannesburg } \\
\text { Declaration on Sustainable Development }\end{array}$ & $\begin{array}{l}\text { An agreement was made to halve the proportion of people who are unable to reach or to } \\
\text { afford safe drinking water and the proportion of people who do not have access to basic } \\
\text { sanitation by the year } 2015 \text {. }\end{array}$ \\
\hline 2003 & First edition of the World Water Report & $\begin{array}{l}\text { Sanitation provisions were summarized as (1) safe and convenient sanitation, (2) toilet } \\
\text { use, (3) public health issues and (4) hygiene behavior. }\end{array}$ \\
\hline 2006 & Sanitation objective of Hashimoto Action Plan & $\begin{array}{l}\text { Accelerated research on alternative models and technologies to improve sanitation such } \\
\text { as eco-sanitation, the vacuum car and treatment plant system, and urine separation from } \\
\text { sewage was targeted in the academic and scientific communities. }\end{array}$ \\
\hline
\end{tabular}

Further improvement of sanitation facilities should be considered especially on their pollutant discharge reduction function as a benefit of wastewater treatment facilities. The proportion of people with improved sanitation was $80 \%$ in 1990 and $99 \%$ in 2004 in Thailand (United Nations, 2007; UNDP, 2006). These figures show that Thailand is well equipped with appropriate sanitation. However, water quality deterioration in the rivers and canals is still one of the important environmental problems to be solved especially in the central area of Thailand including Bangkok (World Bank, 2001; Pollution Control Department (PCD), 2006a).

In the academic sector, various studies have been conducted to clarify the relationships between anthropogenic and natural pollutant discharges and water quality in ambient water. Land-based pollutant load analyses have been conducted to clarify the relationships between pollutant discharges and pollutant loads in rivers (Kunimatsu and Muraoka, 1989; Hosoi et al., 1996; Friedler and Butler, 1996; Ichiki et al., 1996; Sarikaya et al., 1999; Schreiber et al., 2001; Takeda and Fukushima, 2004; 2006; Wakida and Lerner, 2005; Donohue et al., 2006; Stutter et al., 2007). Researches on integrated water resource management (IWRM) (e.g. Butler \& Parkinson, 1997; Harremoës, 1997; Larsen and Gujer, 1997) have also been conducted.

Effectiveness and efficiency of wastewater treatment technological options should be assessed using some appropriate indices. Many researches to improve municipal wastewater treatment efficiencies have also been conducted on centralized and on-site treatment systems in developing countries since the end of the last century (e.g. Yu et al., 
1997; Jetten et al., 1997; Fittschen \& Niemczynowicz, 1997; Hanæus et al., 1997; Henze, 1997; Chen and Beck, 1997; Koottatep et al., 2001). Low-cost and decentralized natural treatment systems were recommended for the municipal wastewater treatment systems because of low-organic concentrations in the influent sewage and high organic compound degradability in tropical climate (Giri et al., 2006). The same types of systems were also recommended based on the results of life cycle assessment (LCA) of wastewater treatment system in Bangkok City (Koottatep and Chaosakul, 2005). Suharyanto and Matsushita (2009) discussed similarities and differences between sanitation systems in Japan and Thailand. When appropriateness and effectiveness of overseas development assistance (ODA) projects in sanitation sector are considered, several technological options should be included in the preliminary project design phase as described by Jarusombat and Wajjwalku (2003).

Tsuzuki (2006a) conducted pollutant load analyses on municipal wastewater and proposed pollutant discharge per capita (PDC) and pollutant load per capita flowing into water body $\left(\mathrm{PLC}_{\mathrm{wb}}\right)$ as effective and efficient indicators of the municipal wastewater contribution to water pollution in the receiving water body. PDC is estimated with pollutant generation per capita (PGC) and pollutant removal efficiency of municipal wastewater treatment methods (Eqs. 1 and 2). The first one is for a specific wastewater treatment method:

$\left(P D C_{-} P O L_{j}\right)_{i}=P G C_{j} \times \frac{\left(100-W T E_{i, j}\right)}{100}$

where $\left(P D C_{P} P O L_{j}\right)_{i}$ is PDC of pollutant $\mathrm{j}$ with municipal wastewater treatment method $\mathrm{i}\left(\mathrm{g}_{\text {person }}{ }^{-1}\right.$ day $\left.^{-1}\right) ; P G C_{j}$ is PGC of pollutant $\mathrm{j}\left(\mathrm{g}\right.$ person ${ }^{-1}$ day $\left.^{-1}\right)$; and $W T E_{i, j}$ is wastewater treatment efficiency of pollutant $\mathrm{j}$ with municipal wastewater treatment method i (\%). The second one is for an area with mixed treatment methods:

$P D C_{-} P O L_{j}=\frac{\sum\left\{\left(P D C_{-} P O L_{j}\right)_{i} \times P O P_{i}\right\}}{\sum P O P_{i}}$

where $P D C_{-} P O L_{j}$ is population averaged $P D C$ of pollutant $\mathrm{j}$ in an area $\left(\mathrm{g}\right.$ person ${ }^{-1}$ day $\left.^{-1}\right) ; P O P_{i}$ is population served with municipal wastewater treatment method $\mathrm{i}$ in the area (person).

$\mathrm{PLC}_{\mathrm{wb}}$ is estimated with PDC and reaching ratio of a pollutant in receiving water (Eq. 3). Pollutant reaching ratio is estimated based on the overall pollutant load analyses in the drainage areas or the river basins. The indicator, $\mathrm{PLC}_{\mathrm{wb}}$, reflects both treatment efficiencies of anthropogenic municipal wastewater treatment systems and natural water purification effects in ambient water. The equation is given as

$\left(P L C_{w b}-P O L_{j}\right)_{i}=\left(P D C_{-} P O L_{j}\right)_{i} \times \frac{R R_{j}}{100}$

where $\left(P L C_{w b} P O L_{j}\right)_{i}$ is $\mathrm{PLC}_{\mathrm{wb}}$ of pollutant $\mathrm{j}$ with municipal wastewater treatment method $\mathrm{i}\left(\mathrm{g}_{\mathrm{g}} \overline{-}_{\mathrm{s} o \mathrm{n}^{-1}} \mathrm{day}^{-1}\right)$; and $R R_{j}$ is reaching ratio of the pollutant $\mathrm{j}(\%)$.

Reaching ratio is estimated with total pollutant discharge of a pollutant in an area and 
pollutant load of the pollutant in ambient water including rivers (Eq. 4) and given as

$R R_{j}=\frac{P L_{j}}{\sum\left(P D_{j, k}\right)}$

where $P L_{j}$ is pollutant load of pollutant $\mathrm{j}$ in the receiving water body including rivers $(\mathrm{t}$ day $\left.^{-1}\right)$; and $P D_{j, k}$ is pollutant discharge of pollutant $\mathrm{j}$ from pollutant source $\mathrm{k}\left(\mathrm{t}\right.$ day $\left.{ }^{-1}\right)$.

Scientific aspects and values of these municipal wastewater pollutant indicators have not been well discussed in scientific papers especially in sanitation policy and wastewater management in developing countries. The symbol $\left(P D C_{-} P O L_{j}\right)_{i}$ is known as pollutant discharge unit load or haisyutsu gentan' $i$ in Japanese. Unit loads are usually applied per capita for municipal wastewater, per area for nonpoint sources, and per production amount for industrial sources. One of the merits of PDC is that it is applicable as an indicator in an area with mixed wastewater treatment systems. PDC and $\mathrm{PLC}_{\mathrm{wb}}$ are fundamental indicators in wastewater treatment planning and river basin-based pollutant load analyses (e.g. Kunimatsu and Muraoka, 1989; Japanese Sewage Works Association, 1997).

Guo and Yang (2003) conducted regression analysis between water pollution and economic level in the Lower Mekong Basin in 1985 to 2000 and found little evidence to support the environmental Kuznets curve (EKC) hypothesis. However, they found out that water pollution including total phosphorus (TP) and chemical oxygen demand (COD) had been significantly related to income level, and Thailand had the least water pollution in the LMB. Moreover, water pollution is a major environmental problem in the Central Thailand area (World Bank, 2001; PCD, 2006a). PDCs were considered to be more reasonable water quality indices to be analyzed against income level (Tsuzuki, 2007; 2008; 2009b). Relationships between PDCs and water, sanitation and economic parameters were statistically analyzed and EKC like inverted U-shaped curve relationships were found in some cases (Tsuzuki, 2006a,b; 2007; 2008; 2009b). Water management in the Southeast Asian countries was discussed focusing on urban water-related environments (Marcotullio, 2007). The comprehensive approach by Marcotullio (2007) encompassed the MDGs indicator, economic development, ambient water quality, coastal environment, pollutant flux in the ambient water, flooding, and cost for improving the situations, and summarized the water-related challenges in local, city-wide, and regional and global scales. In addition to the macro-scale approach by Marcotullio (2007), our micro-scale approach is necessary to clarify some relationships among these phenomena. This is because municipal pollutant discharge per capita is handled only briefly in the actual wastewater treatment planning project, and some complicated features have been found in recent studies (Ii and Fujita, 2005; Ebise and Kawamura, 2008; Sugimoto et al., 2008).

Both costs and benefits of sanitation systems should be considered to improve ambient water quality. Affordability has been emphasized in urban sanitation (e.g. Mara, 1996; Tsuzuki, 2006a; Tsuzuki et al., 2008b). When affordability in sanitation sector is large, water quality improvement can be achieved more easily. There are also conceptional problems in municipal sewerage/excreta management in Thailand (Ludwig and Mohit, 
2000).

A previous study of PDCs estimation in Pak Kret Municipality, a peri-urban area of Bangkok, Thailand, showed larger contribution of seepage and septage from septic tanks and leachate from composting (hereafter refers to SSL unless otherwise described) to pollutant loads in ambient water (Tsuzuki et al., 2008a). Estimated PDCs in Thailand were generally found to be larger than those in Japan. The estimation results quantitatively showed possibility of ambient water quality improvement by pollutant discharge reduction with larger treatment efficiency of the treatment methods in a country with larger MDG sanitation indicator.

In this paper, we first reviewed papers and documents focusing on the water quality profiles in ambient water and municipal wastewater pollutant discharges in Bangkok area, Thailand. Second, pollutant loads in the Chao Phraya River were estimated based on the existing water quality and flow rate data to update the estimation results of pollutant indicators obtained by Tsuzuki et al. (2008a,b). Third, scenario-based water quality predictions were conducted for the corresponding section of the research area in the Chao Phraya River. Fourth, relationship between pollutant discharge reduction function of on-site treatment systems and their construction costs were compared based on the existing literatures and database. The pollutant discharge reduction function was indicated by PDC.

\section{METHODS}

\section{Description of the research area}

Pak Kret District (Amphoe) is located northeast of Notanburi Province, north of Bangkok (Figure 1). The urban sub-district or Pak Kret Municipality is situated on the left bank of the Chao Phraya River and consisted of five communities (Tambon) among the twelve communities in the Pak Kret District. Total area of Pak Kret Municipality area is $36.04 \mathrm{~km}^{2}$ and the total population was 242,800 including 80,000 non-registered inhabitants, which were rather normal in social systems in Thailand. The population density was 6,728 persons $\mathrm{km}^{-2}$ at the end of 2003 (Sinsupan, 2004).

In Bangkok Metropolitan Area (BMA), 4.65 million $\mathrm{m}^{3}$ day $^{-1}$ or $91 \%$ of total water supply source is withdrawn from the Chao Phraya and Mae Klong Rivers and the rest, $9 \%$, from deep wells (Jarusombat and Wajjwalku, 2003). Therefore, water quality in the rivers receiving wastewater discharges is important.

\section{Characteristics of the Chao Phraya River}

The Chao Phraya River flows in the central area of Thailand. The basin area is 159,283 $\mathrm{km}^{2}$, annual precipitation is $1,179 \mathrm{~mm}$ year $^{-1}$, annual potential evapotranspiration is $1,538 \mathrm{~mm}$ year ${ }^{-1}$, and annual average discharge is $196 \mathrm{~m}^{3} \mathrm{~s}^{-1}$ (Working Group of ONWRC of Thailand, 2003). Major dams in the river basin are Bhuminphol Dam completed in 1963 and filled for the first time in 1970, and Sirikit Dam completed in 1972. Effective storage capacities of these dams are 9.7 and 6.7 billion $\mathrm{m}^{3}$, respectively. These two dams control the runoff from $22 \%$ of the entire drainage area of the river. Among a number of barrages developed in the Lower Chao Phraya River basin, larger barrages are the Rama VI barrage completed in 1924, and the Chao Phraya (Chainat) 
diversion dam completed in 1957. The central government policy of water quality was established based on the National Economic and Social Development Plan, and the National Policy and Plan for Natural Resources and Environment Management. The national goal of water quality was determined to maintain the surface water quality at the 1996 level. Priorities in the Chao Phraya River basin was determined as health, cities, water sharing, governance and risk management as one of the United Nations Water Assessment Program (WWAP)'s eleven predetermined challenge areas (UNESCO-WWAP, 2003).

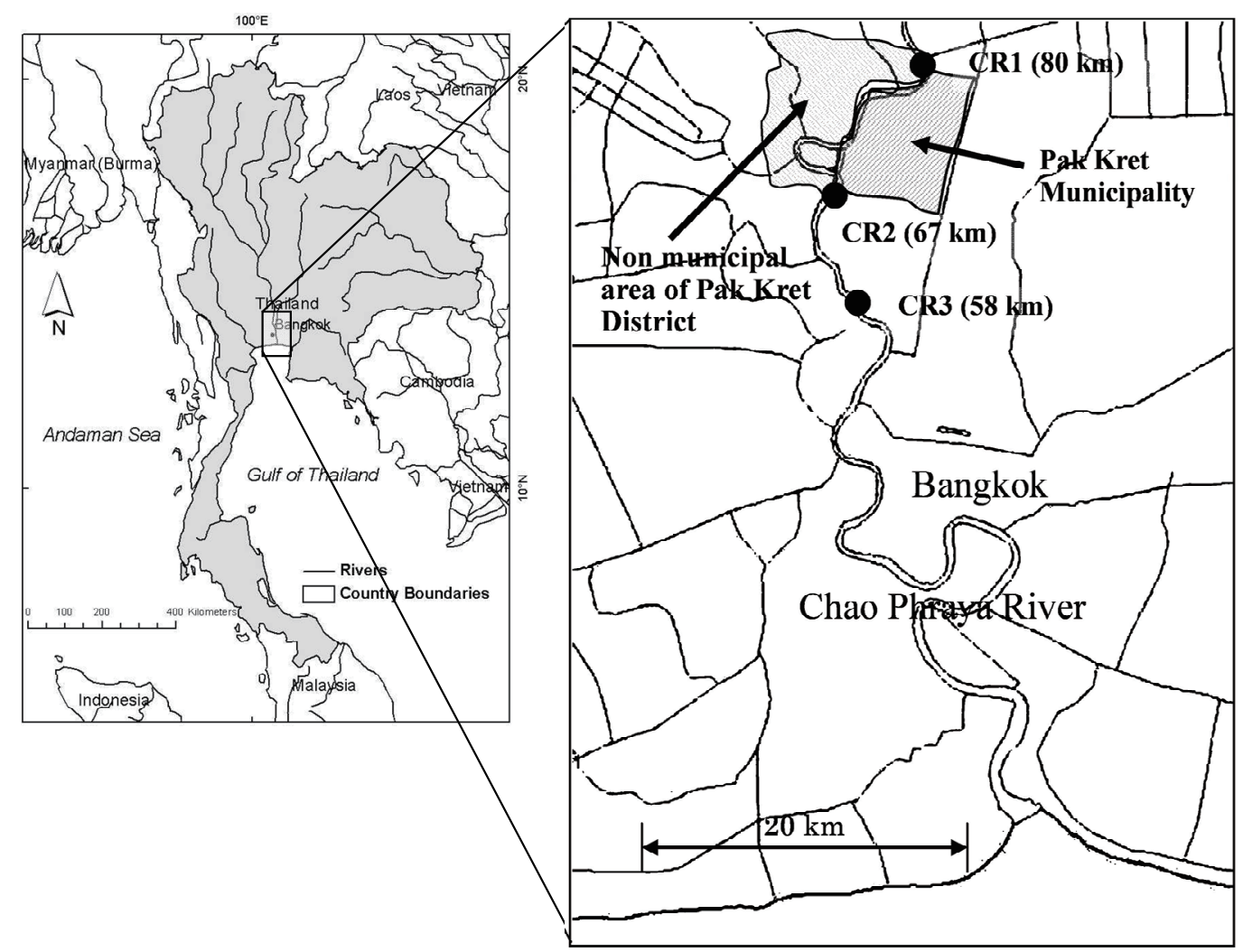

Figure 1 - Research area for this study in the lower section of the Chao Phraya River (Distance from the river mouth is shown in parentheses).

Elevation of river bed and water surface, width of river bed, and cross sectional area of the Chao Phraya River were summarized by Apichatvullop (1976) and Lohani et al. (1980). The research area of this paper was along 67-80 km section in the Chao Phraya River from the river mouth, and cross sectional area of the river was estimated as around 5,000 $\mathrm{m}^{2}$ near the river mouth and 2,000-3,000 $\mathrm{m}^{2}$ at $60-104 \mathrm{~km}$ from the river mouth. Flow rate was smaller from December to July, and larger from August to November, when monthly average flow rate exceeded $500 \mathrm{~m}^{3} \mathrm{~s}^{-1}$. The annual average flow rate was estimated as $479 \mathrm{~m}^{3} \mathrm{~s}^{-1}$ (Apichatvullop, 1976). According to Apichatvullop (1976), in the lower section of the Chao Phraya River, well-mixed condition existed at low and moderate river flow up to $200 \mathrm{~m}^{3} \mathrm{~s}^{-1}$, and partially-mixed condition that existed at larger river flow rate exceeded $200 \mathrm{~m}^{3} \mathrm{~s}^{-1}$. The fluctuation of salinity was found to be a trigonometrical function curve that coincides with the tidal fluctuation. Horizontal flow rate distribution by the distance from the river mouth at a time in a year was estimated by Lohani et al. (1980). 
Typical boundaries between salt and fresh water, remittent and unidirectional flow, and water level variability with tidal level fluctuation were summarized in relation to distance from the river mouth and river discharge (Chay, 1973). Major biological oxygen demand (BOD) pollutant sources in the Chao Phraya estuary were summarized as (1) canals (klongs) serving as outfalls during ebb tide and storing the waste during high tide, (2) direct discharge of wastes into the river by people living on boats or properties contiguous to the river, (3) industrial wastes discharged by a number of small industrial plants located along the river banks, and (4) refuse and garbage dumped directly into the river (Pescod and Ratasuk, 1968). Among the BOD pollutant sources, pollutant contributions from the canals were estimated as largest at that time. BOD pollutant load from the twelve major canals in Bangkok were also summarized (Kasesman, 1970; Chay, 1973). Kasesman (1970) estimated BOD discharge per capita (PDC_BOD) of domestic and industrial wastewater as $57 \mathrm{~g}$ person $^{-1}$ day $^{-1}$, which was estimated from the data of Camp, Dresser and McKee (1968) with PDC_BOD of municipal wastewater as $55 \mathrm{~g}$ person $^{-1}$ day $^{-1}$. BOD discharges by sewer, households on river bank, factories and canals were also summarized by Lohani et al. (1980). Water quality evaluated with BOD and DO in the lower Chao Phraya River was mostly deteriorated among surface water in the Central Thailand area (World Bank, 2001; PCD, 2006a).

\section{Pollutant load profiles in the Chao Phraya River}

Horizontal water quality profiles in the Chao Phraya River in 1999-2000 were summarized based on the administrative data (PCD, 2006c; Tsuzuki et al., 2007a,b; 2008a,b). Annual average flow rate at each point of the river was estimated based on the flow rate profile by Lohani et al. (1980) and annual average discharge at the river mouth estimated by Working Group of ONWRC of Thailand (2003), $196 \mathrm{~m}^{3} \mathrm{~s}^{-1}$. Horizontal profiles of annual average pollutant loads of $\mathrm{BOD}$, the sum of the inorganic nitrogen parameters, $\Sigma \mathrm{N}\left(=\mathrm{NO}_{2}-\mathrm{N}+\mathrm{NO}_{3}-\mathrm{N}+\mathrm{NH}_{4}-\mathrm{N}\right)$ and $\mathrm{TP}$ in the river were estimated from the annual average horizontal river water quality profiles (PCD, 2006c; Tsuzuki et al., 2007a,b; 2008a,b) and the flow rate profile.

\section{Municipal wastewater and nonpoint pollutant discharge analysis}

Municipal wastewater pollutant load analysis in Pak Kret Municipality was conducted in urban and peri-urban area of Bangkok, Thailand, in the previous studies (Tsuzuki et al., 2007a; 2008a). In this study, pollutant load analysis in the Chao Phraya River was updated from Tsuzuki et al. (2008a,b) based on the existing literatures, i.e. pollutant discharges from Pak Kret District on both sides of the river were estimated, and $\mathrm{PLC}_{\mathrm{wb}}$ estimation was also conducted. PDC values applied in this study were PDCs with SSL, i.e. $48.4 \mathrm{~g}_{\text {-BOD person }}{ }^{-1}$ day $^{-1}, 12.4 \mathrm{~g}_{\text {-TN person }}{ }^{-1}$ day $^{-1}$, and $2.38 \mathrm{~g}$-TP person ${ }^{-1}$ day $^{-1}$, which were estimated based on the material flux analysis (MFA) results (Sinsupan, 2004; Tsuzuki and Thammarat, 2008; Tsuzuki et al., 2008a,b). Because of the geographic flatness of the lands around Bangkok, the groundwater level is rather high. Therefore, pollutant discharge estimation results with SSL should be rather reliable to evaluate municipal wastewater contributions to ambient water pollution.

Land use data were obtained from the International Steering Committee for Global Mapping (2008). The values of pollutant discharges per land area (PDLs) for BOD, total nitrogen (TN) and TP from build-up area, agriculture area, forest and mixed area in 
Japan were mostly applied from Kunimatsu and Muraoka (1989) because of data availability. There have been many researches in the fields of point and nonpoint sources in Thailand (Thapinta et al., 2008). However, comprehensive summary of land unit loads or pollutant discharges per land area by land uses are not available in Thailand.

Pollutant loads in the Chao Phraya River corresponding to Pak Kret District including municipal area, Pak Kret Municipality, and non municipal area were estimated. Pollutant load increases were estimated between the corresponding monitoring points for Pak Kret District, i.e. pollutant load increases between 80 and $67 \mathrm{~km}$ from the river mouth (Figure 1). The sum of inorganic nitrogen, $\Sigma \mathrm{N}$, is actually different from $\mathrm{TN}$ which includes both organic and inorganic nitrogen. However, in the estimation, $\Sigma \mathrm{N}$ was applied as TN because of data availability. The estimation method of PLC $\mathrm{Cb}_{\mathrm{wb}}$ applied in the analyses in Japan (Tsuzuki, 2004; 2005; 2006a) was with targeted water body as the river mouth. The same method was considered unreasonable to evaluate contributions of land-based pollutants to ambient water pollutant loads. The reasons for the unreasonableness are that most concerned section of water quality should be along BMA, i.e. 20-80 km from the river mouth (Figure 2), and there is the existence of larger tidal flow in the lower section of the river because of riverbed flatness (Apichatvullop, 1976). Therefore, the pollutant load increases at $67 \mathrm{~km}$ from the river mouth were regarded as the point for estimation of PLC $_{w b}$ in this study.

In the general air quality monitoring stations, annual average value of total suspended particle (TSP) was $0.09 \mathrm{mg} \mathrm{m}^{-3}$ and nitrogen dioxide was $21.1 \mathrm{ppb}$ (PCD, 2006a) in Bangkok in 2004, whereas in Japan in 1999, TSP was $0.028 \mathrm{mg} \mathrm{m}^{-3}$ and nitrogen dioxide was $16 \mathrm{ppb}$ (Japanese Ministry of the Environment, 2001). In roadside monitoring stations, annual average value of TSP was $0.18 \mathrm{mg} \mathrm{m}^{-3}$ and nitrogen dioxide was $34.7 \mathrm{ppb}$ in Bangkok in 2004, whereas in Japan in 1999, TSP was $0.037 \mathrm{mg} \mathrm{m}^{-3}$ and nitrogen dioxide was $30 \mathrm{ppb}$. Average annual precipitation in Pak Kret Municipality is $1,650 \mathrm{~mm} \mathrm{year}^{-1}$ (Polprasert, 2007), which is almost the same as the average annual precipitation in Japan. The air quality data comparisons do not necessarily show the similarity of the air quality between Bangkok and Japan, and precipitation frequency and pattern in Pak Kret Municipality are not necessarily similar to Japan. However, PDL values in Japan were applied because of data availability.

\section{Scenario-based water quality estimation}

Water quality predictions were conducted based on PDCs and $\mathrm{PLC}_{\mathrm{wb}}$ estimated in this paper (Table 2). Wastewater treatment efficiency of BOD with packaged wastewater treatment systems was defined based on the wastewater discharge regulations for buildings and housings (PCD, 2006b) as $80 \%$, and those of nutrient parameters were defined as $20 \%$ for both TN and TP based on average values of combined johkasou (CJ) in Japan because of data availability. Treatment efficiencies of pollutants at existing centralized domestic wastewater treatment plants (WWTPs) in Thailand differed much based on the influent organic pollutant concentrations and wastewater treatment methods (Tsuzuki et al., 2009). Therefore, treatment efficiencies at WWTPs were arbitrarily defined in two cases of Scenario 2, 2a and 2b (Table 2). Predictions of pollutant discharges and water quality in the Chao Phraya River were conducted for the three scenarios, i.e. Scenario 1, 2a and 2 b. 
Table 2 - Conditions of scenario-based estimations

\begin{tabular}{|c|c|}
\hline Scenario & Conditions \\
\hline Scenario 1 & $\begin{array}{l}\text { Current on-site treatment systems with SSL are to be converted to the } \\
\text { packaged on-site wastewater treatment systems without SSL (Tsuzuki et al., } \\
\text { 2009). }\end{array}$ \\
\hline Sencario 2 & $\begin{array}{l}\text { Centralized WWTPs and piped collection systems of both black and gray } \\
\text { water are to be constructed in Pak Kret Municipality. }\end{array}$ \\
\hline Scenario $2 \mathrm{a}$ & $\begin{array}{l}\text { Smaller concentration of influent BOD was supposed and removal ratios were } \\
\text { assumed to be } 50 \% \text { for BOD, TN and TP. }\end{array}$ \\
\hline Scenario $2 b$ & $\begin{array}{l}\text { Larger concentration of influent BOD and introduction of nutrient removal } \\
\text { system were supposed and removal ratios were assumed to be } 80 \% \text { for BOD, } \\
\text { TN and TP. }\end{array}$ \\
\hline
\end{tabular}

When the river flow is remittent and most of the river water does not flow into the Gulf of Thailand, the impact of pollutant discharge should be limited to certain specific areas near the discharge points of pollutant sources. Chay (1973) estimated using a water quality simulation model and found that most influenced area from polluted canals were around $20 \mathrm{~km}$ length in the Chao Phraya River. Cross sectional area of the river width near Pak Kret Municipality is 2,000-3,000 $\mathrm{m}^{2}$ (Apichatvullop, 1976; and Lohani et al., 1980). Contributions of pollutant discharge in Pak Kret District to the river water quality increases were estimated as

$$
\begin{aligned}
P O L_{i, \text { cont. }} & =\frac{P O L_{i, \text { disch. }}}{L \times C S A} \times \frac{L \times C S A}{Q} \times \frac{R R_{i}}{100} \\
& =\frac{P O L_{i, \text { disch }}}{Q} \times \frac{R R_{i}}{100}
\end{aligned}
$$

where $P O L_{i, c o n t}$ is contribution of pollutant discharge to water quality increase of pollutant $\mathrm{i}\left(\mathrm{g} \mathrm{m}^{-3}\right), P O L_{i, \text { disch. }}$ is pollutant discharge of pollutant $\mathrm{i}\left(\mathrm{g} \mathrm{day}^{-1}\right), L$ is length of the specific river section $(\mathrm{m}), C S A$ is cross sectional area of the specific river section $\left(\mathrm{m}^{2}\right), Q$ is flow rate of the river $\left(\mathrm{m}^{3}\right.$ day $\left.^{-1}\right)$, and $R R_{i}$ is reaching ratio of pollutant $\mathrm{i}(\%)$.

Scenario-based water quality predictions were conducted based on estimated water quality at $67 \mathrm{~km}$ from the river mouth using interpolation method with the current annual average water quality of the Nonthaburi Bridge monitoring point (CH15), $83 \mathrm{~km}$ from the river mouth, and Rama 6 Bridge $(\mathrm{CH} 12), 58 \mathrm{~km}$ from the river mouth, as 1.93 $\mathrm{g}-\mathrm{BOD} \mathrm{m} \mathrm{m}^{-3}, 1.28 \mathrm{~g}-\mathrm{TN} \mathrm{m}^{-3}$ and $0.234 \mathrm{~g}-\mathrm{TP} \mathrm{m}^{-3}$.

\section{Cost-benefit comparison and additional PDC estimations}

Pollutant discharge reduction is considered to be a benefit of sanitation in this paper and evaluation of the benefit is conducted by the use of PDCs. In order to address affordability of municipal wastewater treatment methods, the relationship between construction cost and PDCs was summarized based on the existing database (Water Environment Partnership in Asia (WEPA), 2007). The WEPA database has been developed by the Institute for Global Environmental Strategies (IGES), Japan. PDCs were estimated using the current wastewater treatment technology data of effluent water quality and construction cost in some Asian countries including Cambodia, Lao PDR, Malaysia, Myanmar, Thailand, Vietnam and Japan.

PDC of CJ and community plants (CP) in Japan were summarized in relation to the 
equivalent population for wastewater treatment based on the existing literatures (Nishimura et al., 2004; Ogawa, 2006). CP is medium-sized on-site treatment plants for both black and gray water. Moreover, PDCs of CJ and CP were also summarized based on the existing literatures (Nishimura et al., 2004; Ogawa, 2006) to reassure PDC estimations in Japan by Tsuzuki (2006a).

\section{RESULTS}

\section{Pollutant load in the river}

Annual average pollutant loads of BOD, $\Sigma \mathrm{N}$ and TP in the Chao Phraya River were estimated from annual average river water quality (PCD, 2006c; Tsuzuki et al., 2007a,b; 2008a,b) and flow rate (Lohani et al., 1980; and Working Group of ONWRC of Thailand, 2003) as shown in Figure 2. Pollutant loads in the river were found to increase in the river sections corresponding to the BMA.
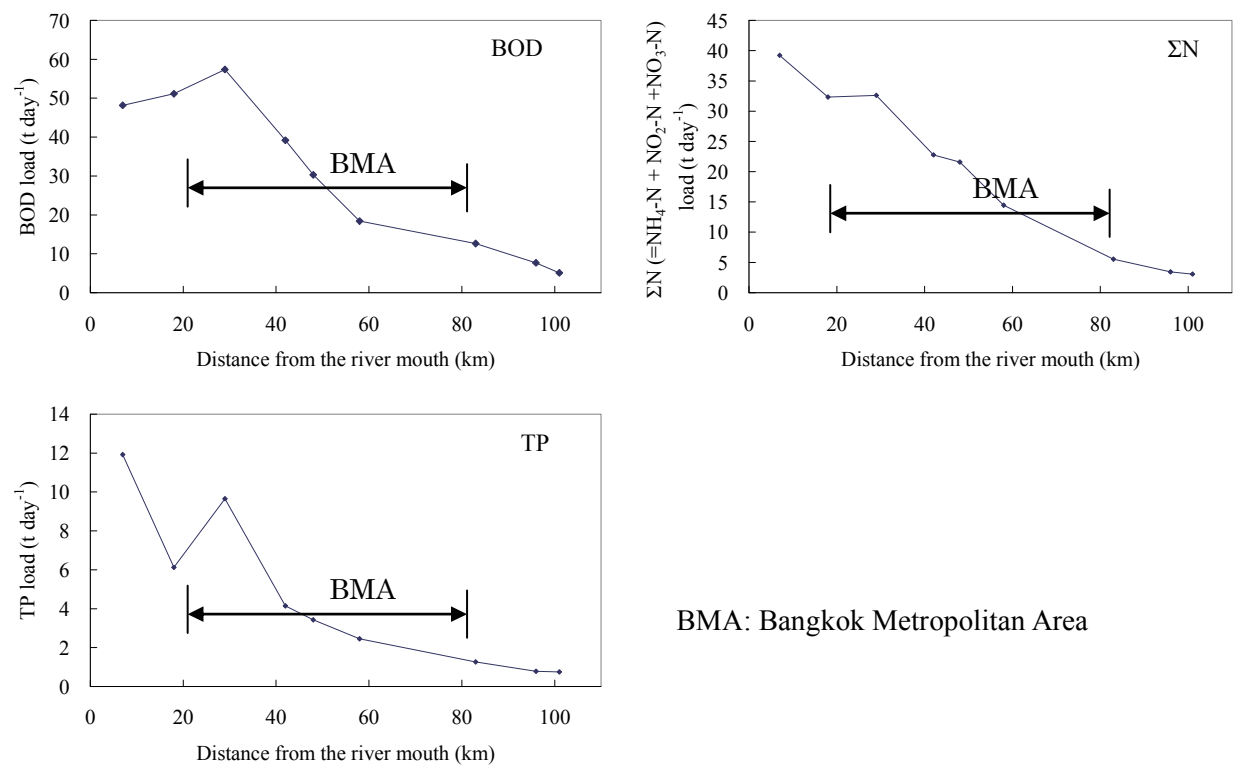

BMA: Bangkok Metropolitan Area

Figure 2 - Annual average pollutant loads in the Chao Phraya River (estimated from the horizontal flow rate profile developed by Lohani et al. (1980) and Working Group of ONWRC of Thailand (2003); and water quality data of PCD (2006c) and Tsuzuki et al. (2007a,b; 2008a,b)).

\section{Municipal wastewater and nonpoint pollutant discharge analysis}

Pollutant discharges from nonpoint sources were estimated using land use data in Table 3 (International Steering Committee for Global Mapping, 2008) and PDLs in Japan as shown in Table 4. Total pollutant discharges from Pak Kret District were estimated as $663 \mathrm{~kg}-\mathrm{BOD}$ day $^{-1}, 648 \mathrm{~kg}-\mathrm{TN}$ day $^{-1}$ and $25.8 \mathrm{~kg}-\mathrm{TP}$ day $^{-1}$. Total anthropogenic pollutant discharges from households, markets and peri-agriculture were estimated in Pak Kret District and Pak Kret Municipality (Tsuzuki et al., 2008a,b) and population ratio of Pak Kret District to Pak Kret Municipality (Table 3) as shown in Table 5. Total anthropogenic pollutant discharges from Pak Kret District were estimated as 19.6 t-BOD day ${ }^{-1}, 5.54$ t-TN day ${ }^{-1}$ and 1.11 t-TP day ${ }^{-1}$ (Table 5). Pollutant discharge contributions of the non-point sources to total pollutant discharges were estimated as $12 \%$ for TN and less than $10 \%$ for BOD and TP (Table 5, Figure 3). Municipal 
wastewater pollutant discharges occupied most of the pollutant discharges from Pak Kret District. Nonpoint source contributions were only around or less than $12 \%$ of the total pollutant discharges. Therefore, overall pollutant discharge estimation method with PDL values in Japan was considered to be acceptable.

Table 3 - Population, population density, land use of municipal and non-municipal areas of Pak Kret District.

\begin{tabular}{|c|c|c|c|c|c|c|c|c|c|c|}
\hline \multirow[t]{2}{*}{ Area } & \multirow[t]{2}{*}{$\begin{array}{c}\text { Population }^{\mathrm{a}} \\
\text { person }\end{array}$} & \multirow[t]{2}{*}{$\begin{array}{c}\begin{array}{c}\text { Population } \\
\text { percentage }\end{array} \\
\\
\%\end{array}$} & \multirow[t]{2}{*}{$\begin{array}{c}\text { Population }^{\mathrm{b}} \\
\text { person }\end{array}$} & $\begin{array}{l}\text { Land use }^{\mathrm{c}} \\
\text { Agricultural } \\
\text { area }\end{array}$ & \multirow{2}{*}{$\begin{array}{l}\text { Grassland/ } \\
\text { shrub } \\
\mathrm{km}^{2} \\
\end{array}$} & \multirow[t]{2}{*}{$\begin{array}{l}\text { Built-up } \\
\text { area } \\
\mathrm{km}^{2}\end{array}$} & \multirow{2}{*}{$\begin{array}{c}\text { Mixture } \\
\mathrm{km}^{2} \\
\end{array}$} & \multirow[t]{2}{*}{$\begin{array}{l}\begin{array}{l}\text { Total } \\
\text { area }\end{array} \\
\mathrm{km}^{2} \\
\end{array}$} & \multirow[t]{2}{*}{$\begin{array}{l}\text { Percentage } \\
\text { of area } \\
\\
\% \\
\%\end{array}$} & \multirow[t]{2}{*}{$\begin{array}{l}\text { Population } \\
\text { density } \\
\text { person } \mathrm{km}^{-2}\end{array}$} \\
\hline & & & & $\mathrm{km}^{2}$ & & & & & & \\
\hline Pak Kret District & 177,282 & 100.0 & 302,693 & 72.1 & 13.2 & 2.7 & 0.9 & 89 & 100.0 & 3,401 \\
\hline Pak Kret Municipality & 142,225 & 80.2 & 242,836 & 23.3 & 9.9 & 2.7 & 0.0 & 36 & 40.4 & 6,745 \\
\hline Non-municipal area & 35,057 & 19.8 & 59,857 & 48.8 & 3.3 & 0.0 & 0.9 & 53 & 59.6 & 1,129 \\
\hline
\end{tabular}

Table 4 - Estimated nonpoint pollutant discharges from Pak Kret District by land use $\left(\mathrm{kg} \mathrm{day}^{-1}\right)$.

\begin{tabular}{lccccc}
\hline Pollutant and area & $\begin{array}{c}\text { Agricultural } \\
\text { area }\end{array}$ & $\begin{array}{c}\text { Grassland/ } \\
\text { shrub }\end{array}$ & $\begin{array}{c}\text { Built-up } \\
\text { area }\end{array}$ & Mixture & Total \\
\hline${\text { PDL-BOD }\left(\mathrm{kg} \mathrm{km}^{-2} \text { day }^{-1}\right)^{\mathrm{a}}}^{\mathrm{a}}$ & 5.5 & 0.5 & 90.4 & 13.7 & \\
Pak Kret District & 395 & 7 & 248 & 13 & 663 \\
Pak Kret Municipality & 128 & 5 & 248 & 0 & 381 \\
Non municipal area & 267 & 2 & 0 & 13 & 282 \\
\hline PDL-TN $\left(\mathrm{kg} \mathrm{km}^{-2} \text { day }^{-1}\right)^{\mathrm{a}}$ & 8.2 & 0.8 & 13.6 & 8.2 & \\
Pak Kret District & 593 & 11 & 37 & 8 & 648 \\
Pak Kret Municipality & 192 & 8 & 37 & 0 & 237 \\
Non municipal area & 401 & 3 & 0 & 8 & 411 \\
\hline PDL-TP $\left(\text { kg km }^{-2} \text { day }^{-1}\right)^{\mathrm{a}}$ & 0.27 & 0.03 & 1.81 & 0.82 & \\
Pak Kret District & 19.8 & 0.4 & 5.0 & 0.8 & 25.8 \\
Pak Kret Municipality & 6.4 & 0.3 & 5.0 & 0.0 & 11.6 \\
Non municipal area & 13.4 & 0.1 & 0.0 & 0.8 & 14.2 \\
\hline
\end{tabular}

a: Pollutant discharges per land area (PDLs) were estimated by the authors based on

Kunimatsu and Muraoka (1989).

Pollutant loads in the Chao Phraya River corresponding to Pak Kret District including municipal area, Pak Kret Municipality, and non-municipal area were estimated (Table 5). Increases of pollutant loads between the corresponding monitoring points for Pak Kret District, i.e. increases between 80 and $67 \mathrm{~km}$ from the river mouth, were estimated as 2.9 t-BOD day ${ }^{-1}, 4.1 \mathrm{t}-\mathrm{N}$ day $^{-1}$ and $0.56 \mathrm{t}^{-\mathrm{P}}$ day $^{-1}$ (Tables 5 and 6). Reaching ratios to the point of $67 \mathrm{~km}$ from the river mouth were estimated as $15 \%$ for BOD, $74 \%$ for TN and $51 \%$ for TP (Table 5). PLC $_{\mathrm{wb}}$ at $67 \mathrm{~km}$ from the river mouth were estimated as 7.2 g-BOD person ${ }^{-1}$ day $^{-1}, 9.2$ g-TN person $^{-1}$ day $^{-1}$ and 1.2 g-P person ${ }^{-1}$ day $^{-1}$ (Table 7). Smaller PLC $\mathrm{C}_{\mathrm{wb}}$ of CJ for all the parameters and slightly smaller $\mathrm{PLC}_{\mathrm{wb}}$ of night soil treatment systems (NST) for TN and TP were found by estimation result comparison with the results of a case study in Japan (Tsuzuki, 2006a). BOD load per capita flowing into water body $\left(\mathrm{PLC}_{\mathrm{wb}}\right.$ BOD) in Pak Kret Municipality was found to be larger than that of CJ and smaller than that of simple joukasou (SJ) and NST. TN and TP loads per capita flowing into water body $\left(\mathrm{PLC}_{\mathrm{wb}} \mathrm{TN}\right.$ and $\left.\mathrm{PLC}_{\mathrm{wb}} \mathrm{TP}\right)$ in Pak Kret Municipality were found to be larger than those of CJ, SJ and NST. 
Table 5 - Pollutant discharges from Pak Kret Municipality and District, pollutant load increases in the 67-80 km section of the Chao Phraya River and reaching ratios.

\begin{tabular}{|c|c|c|c|c|c|c|}
\hline Pollutant & $\begin{array}{l}\text { Total } \\
\text { anthropogenic } \\
\text { pollutant } \\
\text { discharge with } \\
\text { SSL in Pak Kret } \\
\text { Municipality }{ }^{\text {a }} \\
\qquad \begin{array}{l}\text { (a) } \\
\quad \text { day }^{-1}\end{array}\end{array}$ & $\begin{array}{l}\text { Total } \\
\text { anthropogenic } \\
\text { pollutant } \\
\text { discharge with } \\
\text { SSL in Pak Kret } \\
\text { District }{ }^{\text {a,b }} \\
\qquad \begin{array}{l}\text { (b) } \\
\text { t day }\end{array}\end{array}$ & $\begin{array}{l}\text { Pollutant } \\
\text { discharge } \\
\text { based on } \\
\text { land use }\end{array}$ & $\begin{array}{l}\text { Total } \\
\text { pollutant } \\
\text { discharge }\end{array}$ & $\begin{array}{l}\text { Pollutant } \\
\text { load } \\
\text { increase at } \\
67-80 \mathrm{~km}\end{array}$ & $\begin{array}{l}\text { Reaching } \\
\text { ratio }\end{array}$ \\
\hline BOD & 15.2 & 18.9 & 0.7 & 19.6 & 2.9 & 15 \\
\hline $\mathrm{TN}$ & 3.92 & 4.89 & 0.65 & 5.54 & 4.1 & 74 \\
\hline $\mathrm{TP}$ & 0.87 & 1.08 & 0.03 & 1.11 & 0.56 & 51 \\
\hline
\end{tabular}

a: Pollutant discharge from households, market and peri-agriculture; b: Estimated from pollutant discharges from Pak Kret Municipality and the ratio of population of Pak Kret District and Municipality.

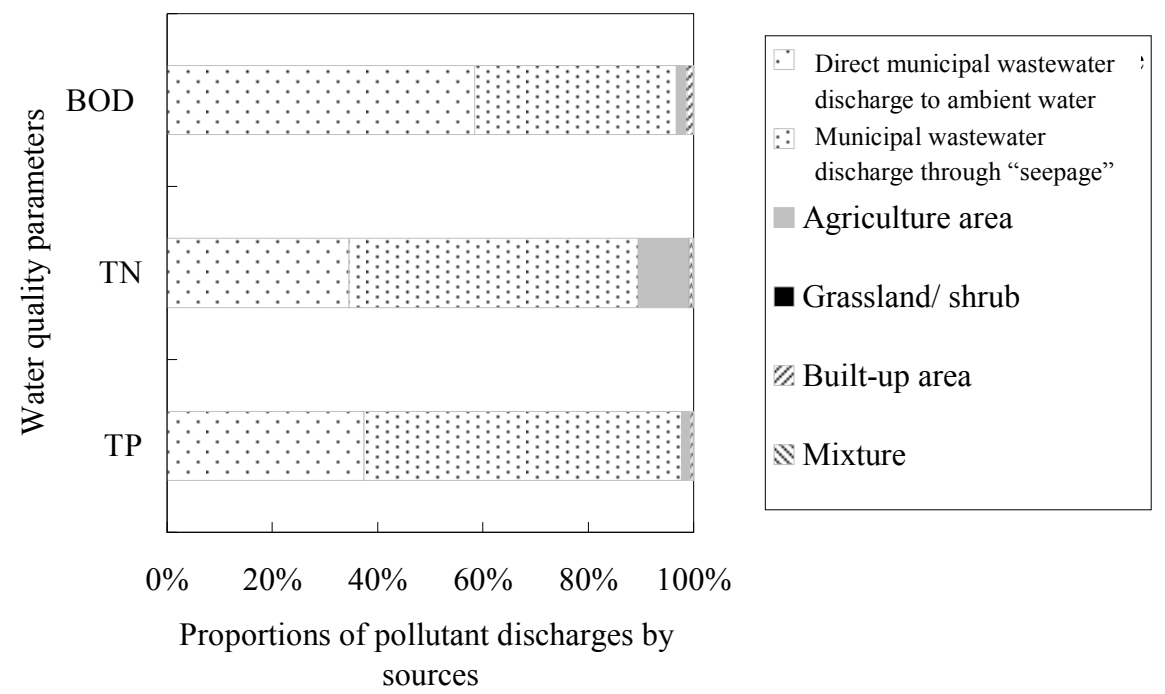

Figure 3 -Proportions of pollutant discharges by sources from Pak Kret District

In the estimations, $\Sigma \mathrm{N}$ was applied for ambient water quality. Pollutant load of $\Sigma \mathrm{N}$ is considered to be underestimated for $\mathrm{TN}$ pollutant load, reaching ratio of nitrogen is considered to be overestimated, and $\mathrm{PLC}_{\mathrm{wb}}$ also overestimated. Larger nitrogen and phosphorus reaching ratios may show necessity of nutrient removal in wastewater treatment facilities especially because eutrophication in ambient water is expected in the tropical climate. 
Table 6 - Annual average pollutant load in the section of $58-80 \mathrm{~km}$ from the river mouth of the Chao Phraya River.

\begin{tabular}{lcrrrr}
\hline $\begin{array}{l}\text { Measurement points in the } \\
\text { Chao Phraya River }\end{array}$ & $\begin{array}{c}\text { Distance from } \\
\text { river mouth }\end{array}$ & Flow rate $^{\mathrm{a}}$ & $\mathrm{BOD}^{\mathrm{b}}$ & $\Sigma \mathrm{N}^{\mathrm{b}}$ & $\mathrm{TP}^{\mathrm{b}}$ \\
\hline A: Pibulsongkram Pier & 58 & $\mathrm{~m}^{3} \mathrm{~s}^{-1}$ & $\mathrm{t} \mathrm{day}^{-1}$ & $\mathrm{t} \mathrm{day}^{-1}$ & $\mathrm{t} \mathrm{day}^{-1}$ \\
B: Wat Tamnak Tai & 67 & 97.4 & 16.3 & 10.0 & 1.89 \\
C: Wat Photong Bon & 80 & 79.8 & 13.4 & 5.9 & 1.34 \\
B-C $^{\mathrm{c}}$ & -13 & 17.6 & 2.9 & 4.1 & 0.56 \\
\hline
\end{tabular}

a: based on Lohani et al., 1980, and Working Group of ONWRC of Thailand, 2003; b: based on the flow rate estmation and average water quality of PCD (2006); c: difference between B and $\mathrm{C}$.

Table 7 - Pollutant load per capita flowing into water body $\left(\mathrm{PLC}_{\mathrm{wb}}\right)$ in Pak Kret Municipality compared with PLC $\mathrm{wb}_{\mathrm{wb}}$ in Japan.

\begin{tabular}{lccc}
\hline $\begin{array}{l}\text { Area; and domestic wastewater } \\
\text { treatment method }\end{array}$ & $\begin{array}{c}\mathrm{PLC}_{\mathrm{wb}} \\
\mathrm{BOD} \\
\text { g person }^{-1} \text { day }^{-1}\end{array}$ & $\begin{array}{c}\mathrm{TN} \\
\text { g person }^{-1} \text { day }^{-1}\end{array}$ & $\begin{array}{c}\mathrm{TP} \\
\text { g person }^{-1} \text { day }^{-1}\end{array}$ \\
\hline $\begin{array}{l}\text { Pak Kret District; Averaged value } \\
\text { Chiba City; Combined Johkasou }\end{array}$ & 7.2 & 9.2 & 1.20 \\
Chiba City; Simple Johkasou & $1.1 \pm 1.4^{\mathrm{a}}$ & $4.4 \pm 2.1^{\mathrm{a}}$ & $0.41 \pm 0.24^{\mathrm{a}}$ \\
$\begin{array}{l}\text { Chiba City; Night soil treatment } \\
\text { system }\end{array}$ & $13.5 \pm 4.9^{\mathrm{a}}$ & $5.0 \pm 2.2^{\mathrm{a}}$ & $0.39 \pm 0.27^{\mathrm{a}}$ \\
\hline
\end{tabular}

a: Average \pm standard deviation in the small drainage areas (Source: Tsuzuki, 2006).

\section{Scenario-based pollutant discharges and water quality prediction}

Municipal wastewater pollutant discharge contributions from Pak Kret District to the river water quality increases were estimated through Eq. 5 as $0.34 \mathrm{mg-BOD} \mathrm{l}^{-1}(18 \%)$, $0.48 \mathrm{mg}-\mathrm{N}^{-1}(38 \%)$ and $0.066 \mathrm{mg}-\mathrm{P}^{-1}(28 \%)$ in consideration with reaching ratios (Table 8).

Table 8 - Water quality increases estimated in the river section corresponding to Pak Kret District.

\begin{tabular}{lllll}
\hline Pollutant & $\begin{array}{l}\text { Pollutant } \\
\text { discharge of }\end{array}$ & $\begin{array}{l}\text { Annual average flow } \\
\text { rate of the Chao Phraya }\end{array}$ & $\begin{array}{l}\text { Annual average } \\
\text { water quality in the }\end{array}$ & $\begin{array}{l}\text { Contribution of pollutant } \\
\text { discharge in Pak Kret }\end{array}$ \\
municipal & River at $67 \mathrm{~km}$ from the & Chao Phraya River & District to the water \\
wastewater in & river mouth & $\begin{array}{l}\text { at } 67 \mathrm{~km} \text { from the } \\
\text { river mouth }\end{array}$ & $\begin{array}{l}\text { quality in consideration } \\
\text { with reaching ratio }\end{array}$
\end{tabular}

\begin{tabular}{lcccccc} 
& $\mathrm{t} \mathrm{day}^{-1}$ & $\mathrm{~m}^{3} \mathrm{~s}^{-1}$ & $\mathrm{~m}^{3}$ day $^{-1}$ & \multicolumn{1}{c}{$\mathrm{g} \mathrm{m}^{-3}$} & $\mathrm{~g} \mathrm{~m}^{-3}$ & $\%$ \\
\hline BOD & 19.6 & 97.9 & $8,460,000$ & 1.93 & 0.34 & 18 \\
TN & 5.54 & 97.9 & $8,460,000$ & 1.28 & 0.48 & 38 \\
TP & 1.11 & 97.9 & $8,460,000$ & 0.234 & 0.066 & 28 \\
\hline
\end{tabular}

Based on the three scenarios, total pollutant discharges from Pak Kret District and water quality at $67 \mathrm{~km}$ from the river mouth were predicted (Figures 4 and 5). Percentages of pollutants discharge reductions were predicted as 23-64\% for BOD, 32-62 \% for TN and $22-52 \%$ for TP in all the scenarios (Figure 4). Due to the pollutant discharge 
reductions, predicted water quality in the Chao Phraya River was 1.7-1.8 $\mathrm{mg}^{-B O D ~ ~^{-1}}$,

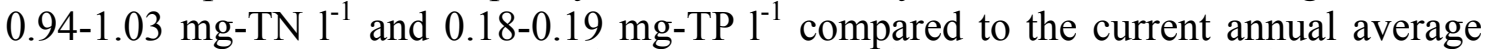

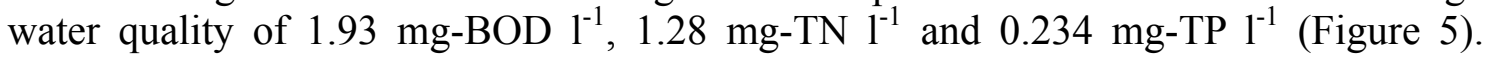
Percentages of water quality improvement were estimated as $6.4-14 \%$ for BOD, $15-26 \%$ for TN and $14-22 \%$ for TP.

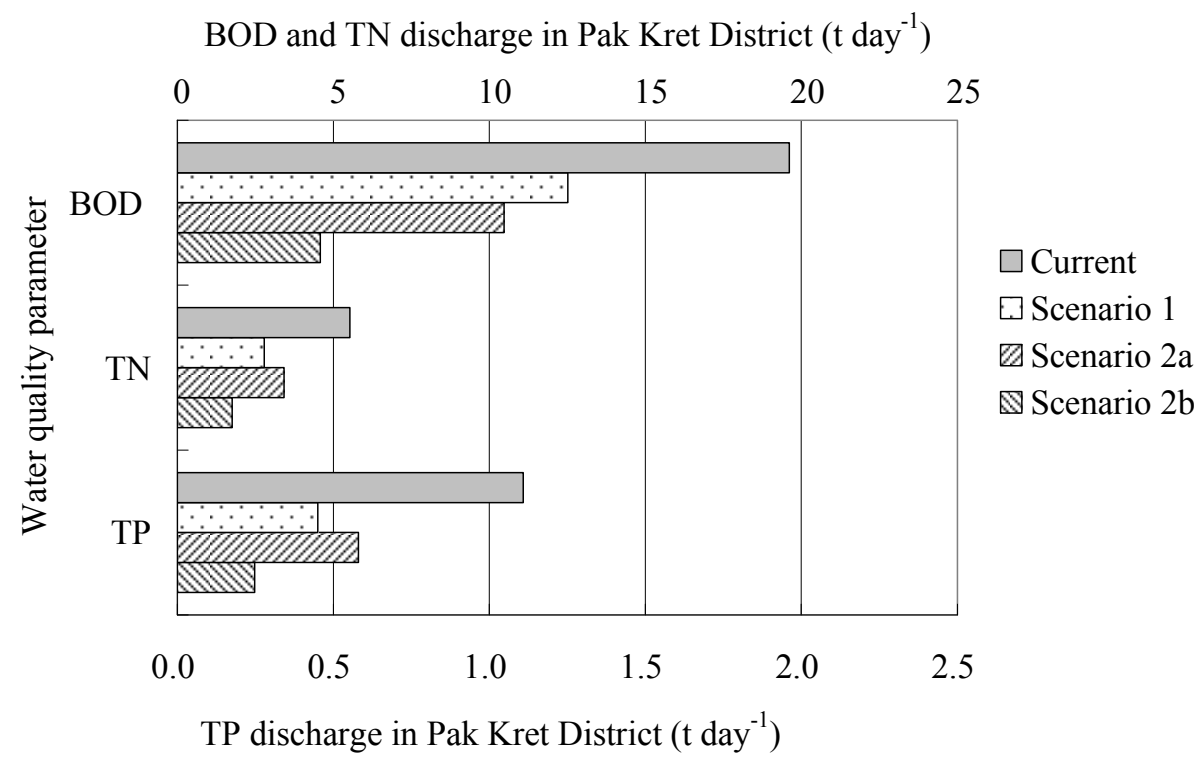

Figure 4 - Pollutant discharges predicted with the scenarios in Pak Kret District.

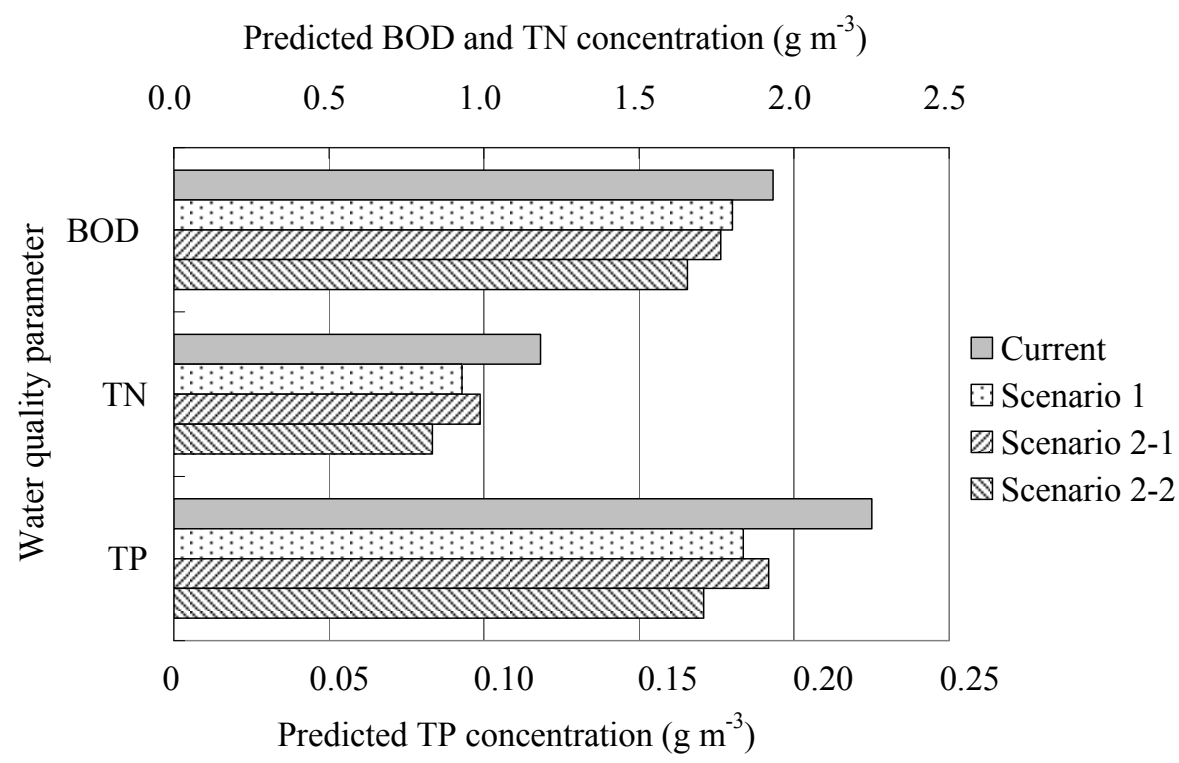

Figure 5 - Water quality in the Chao Phraya River at $67 \mathrm{~km}$ from the river mouth predicted with the Scenario.

\section{Cost-benefit comparison and additional PDCs estimations}

Relationship between PDCs and construction cost per capita of the current wastewater treatment technologies in some Asian countries was summarized based on the database (WEPA, 2007) as shown in Figure 6. In the range of construction cost per capita of USD 
4-2,942 person $^{-1}$, PDCs were estimated as 0.05-9.5 g-BOD person ${ }^{-1}$ day $^{-1}, 0.1-11.3$ g-COD person ${ }^{-1}$ day $^{-1}, 0.4-5.7$ g-TN person $^{-1}$ day $^{-1}$ and 0.02-0.82 g-TP person ${ }^{-1}$ day $^{-1}$. There was no clear relationship between construction cost and PDCs (Figure 6a). Construction cost was USD 19-477 person ${ }^{-1}$ in Thailand and USD 144-2,970 person $^{-1}$ in Japan, where it was found to be the most expensive (Figure 6b).

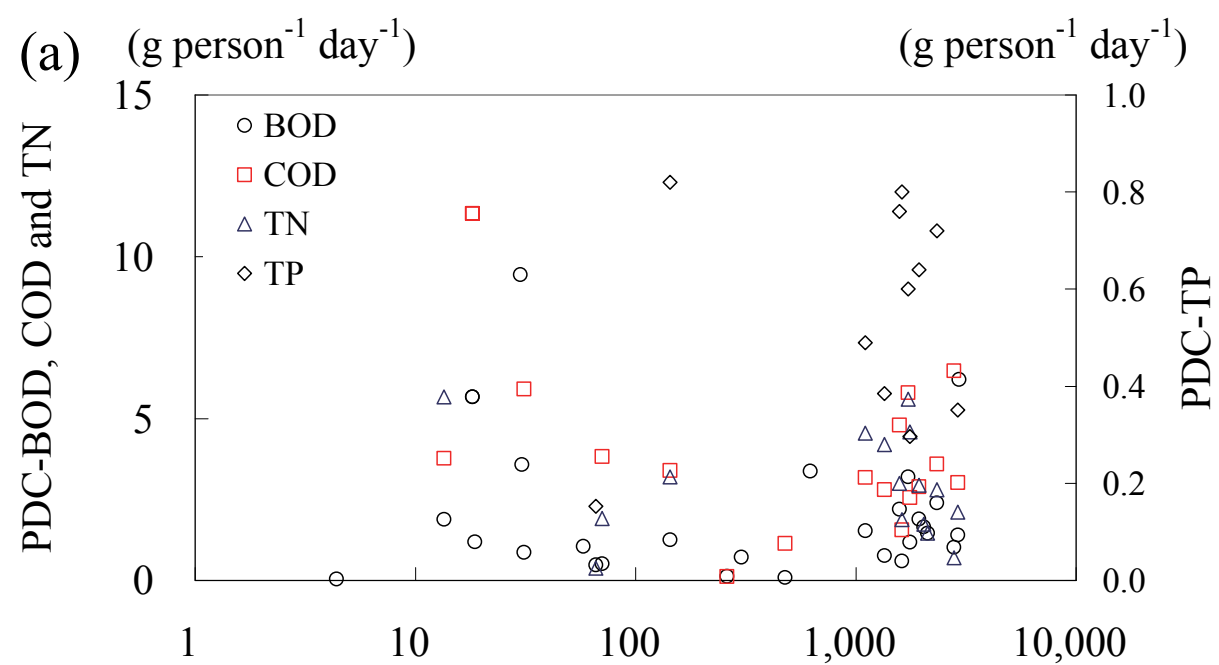

Construction cost per capita (US\$ person ${ }^{-1}$ )

(b) $\left(\right.$ g person $^{-1}$ day $\left.^{-1}\right)$

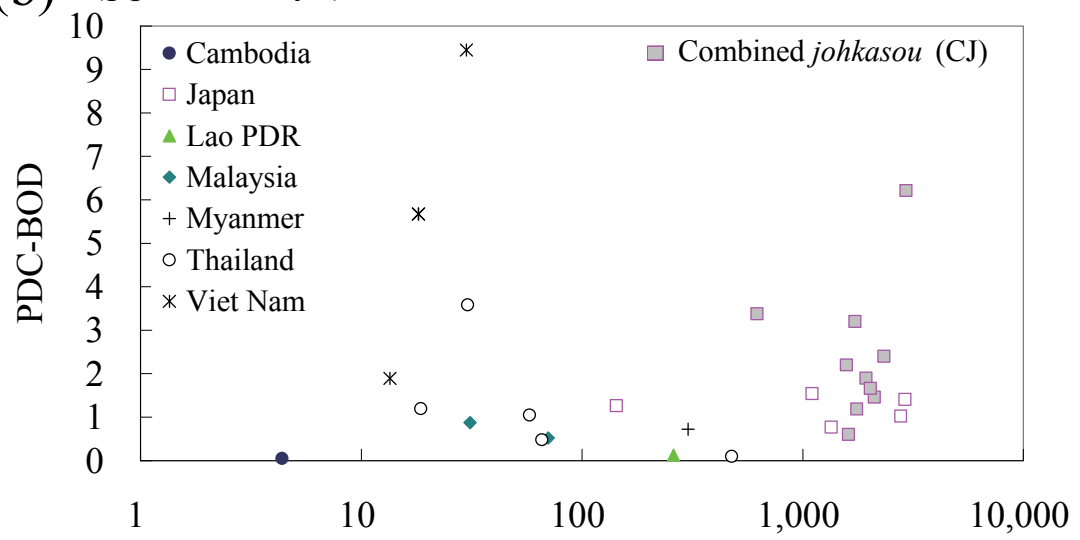

Construction cost per capita (US\$ person ${ }^{-1}$ )

Figure 6 - Relationships between PDCs and construction cost per capita. (a): BOD, COD, TN and TP with centralized and de-centralized domestic wastewater treatment systems in Asian countries; and (b): PDC_BOD with centralized and de-centralized domestic wastewater treatment systems in Asian countries. Combined johkasou (CJ) is an on-site treatment system in Japan (based on WEPA, 2007).

PDCs of CJ and CP in Japan were summarized in relation to the equivalent population for wastewater treatment based on the studies of Nishimura et al. (2004) and Ogawa (2006) as shown in Figure 7. Designed PDC of combined johkasou were around 4 g-BOD person ${ }^{-1}$ day $^{-1}, 3$ g-TN person ${ }^{-1}$ day $^{-1}$ and $0.6 \mathrm{~g}_{\text {-TP }}$ person $^{-1}$ day $^{-1}$ (Figure 7a). PDCs of community plants estimated from measured data were 0.5-6.7 g-BOD person ${ }^{-1}$ 
day $^{-1}, 1.2-4.4$ g-COD $_{\text {Mn }}$ person $^{-1}$ day $^{-1}, 0.9-10.2$ g-TN person $^{-1}$ day $^{-1}$ and 0.3-0.8 g-TP person $^{-1}$ day $^{-1}$ (Figure 7b). PDCs-BOD of CJ and CP estimated by Tsuzuki (2006a) were almost the same as those in Figure 7. However, PDCs-TN and PDCs-TP of CJ and CP estimated by Tsuzuki (2006a) were larger than those in Figure 7. These are because Tsuzuki (2006a) estimated PDCs based on the field survey data including older CJ and $\mathrm{CP}$ with lower nutrient removal efficiencies. PDCs in Figure 7 reflected recent development of nutrient removal function of CJ and CP. Stability and variance of effluent water quality of a treatment method is beyond the scope of this paper.

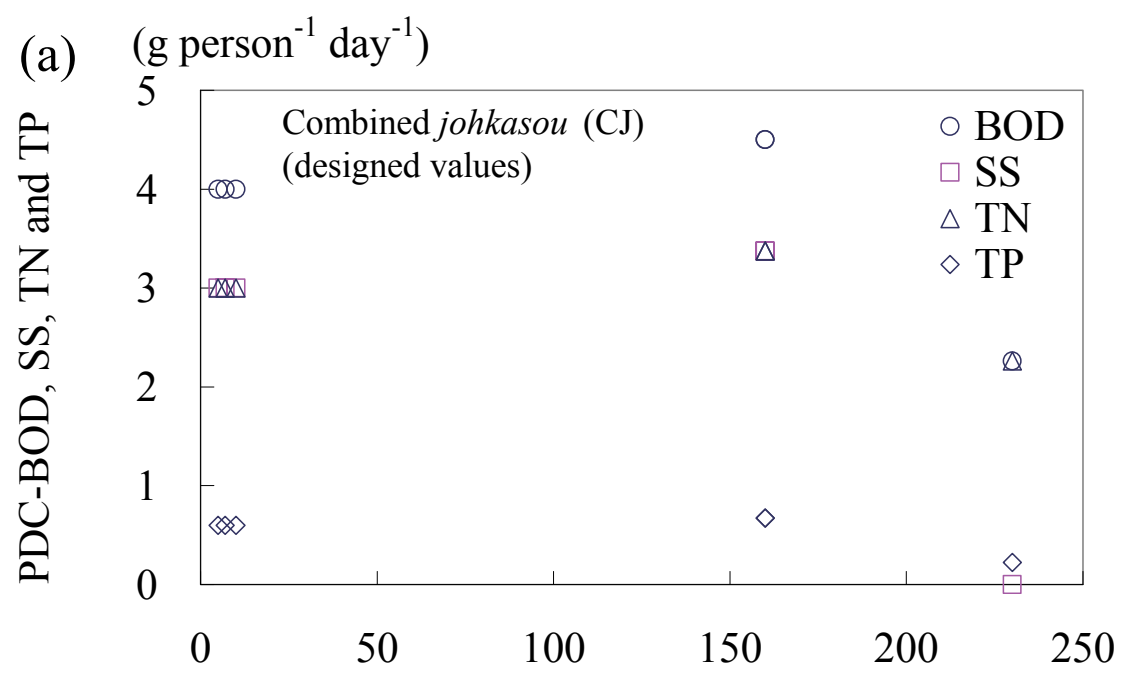

Population equivalent for wastewater treatment (persons)

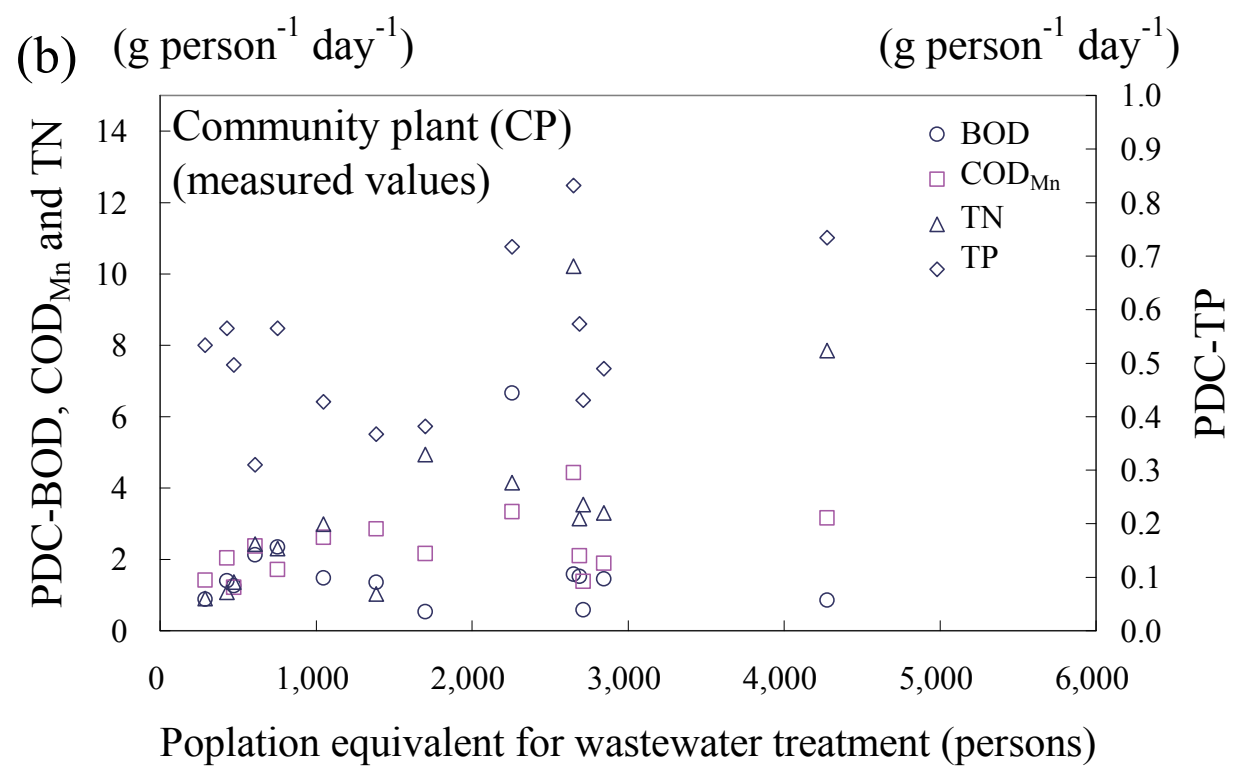

Figure 7 - Designed PDC of combined johkasou (CJ) (a) and measured PDC of community plant (CP) (b) in Japan in relation to population equivalent for wastewater treatment (based on Nishimura et al., 2004, and Ogawa, 2006). 


\section{DISCUSSIONS}

\section{Pollutant discharge reduction benefit of sanitation}

PLC $_{\text {wb }}$ BOD in Pak Kret Municipality estimated in this study was larger than $\mathrm{PLC}_{\mathrm{wb} \_}$BOD of CJ in Chiba City, Japan (Table 7). Nutrient loads per capita flowing into water body, PLC $_{\mathrm{wb}}$ TN and PLC $\mathrm{wb}_{-}$TP in Pak Kret Municipality were larger than those of all on-site treatment systems in Japan. PDC values of CJ shown in Figures 6 and 7 are not the same and within some ranges. Nutrient removal of CJ has been one of the important targets in the development of on-site municipal wastewater treatment systems in Japan these days (e.g. Okumura et al., 2006).

\section{Pollutant discharge and water quality improvement predictions}

In the scenario-based estimation, water quality improvement was predictted as $6.4-14 \%$ for BOD, $15-26 \%$ for TN and 14-22\% for TP (Figures 4 and 5). The prediction was based on pollutant discharge reductions only in Pak Kret Municipality. Water quality can be further improved when pollutant discharge reductions are also conducted with other upper and nearby areas.

For pollutant load analyses, the material flow analysis (MFA) has been applied recently by Schaffner (2007) and Schaffner et al. (2009). PDLs estimated in this study are in the same order as the estimated unit load values from Schaffner (2007) for nitrogen and phosphorus parameters. Schaffner (2007) classified agricultural land as rice, field crops, and fruits and vegetables. For the fruits and vegetables, the smaller values of pollutant discharge unit loads were applied. Therefore, more precise estimation with more minute categories of the agricultural land should be necessary in further research.

The pollutant load analysis result in this paper coincides with that of Noyboonya (2008) that phosphorus discharge contribution from households was found to be larger comparing to other point and non-point sources in the Mae Klong River drainage area, Thailand. Suharyanto and Matsushita (2009) recently presented a comparative study on sanitation systems in Japan and Thailand including pollutant load analysis. Problems of smaller influent concentration at centralized WWTPs may have to be addressed further, however, these kinds of systematic approach is necessary in urban water and wastewater management in Thailand

Wakida and Lerner (2005) conducted nitrogen source estimation in groundwater of the urban area in developed countries and found large contributions of wastewater disposal (on-site systems and leaky sewers) and solid waste disposal (landfills and waste tips). Dulaiova et al. (2006) analyzed groundwater inputs into the Chao Phraya River using radioactive tracer method and estimated groundwater inputs to the river as about $20 \%$ of the river flow in January (dry season) and $4 \%$ during high flow conditions. Quantitative investigation on groundwater pollution from on-site system and on relationship between groundwater and ambient water should be considered for further research.

\section{Comparison of cost and a benefit of sanitation}

PDCs in Thailand (Figure 6b) were estimated only with effluent water quality and quantity of the municipal wastewater treatment systems. Therefore, when SSL were included, PDCs in developing countries including Thailand would be larger than the 
values shown in the figure. Construction cost of sanitation facilities per capita in Thailand was USD 19-477 person $^{-1}$, whereas that in Japan was USD 144-2,970 person ${ }^{-1}$. It is reasonable for ordinary people to choose lower cost facilities with the same pollutant-removal performances. The difference of construction costs between developing and developed countries is one of the barriers to be overcome for introduction or export/import of on-site municipal wastewater treatment systems (Tsuzuki et al., 2008b).

\section{Water quality improvement policies in Thailand}

The estimation and prediction results shown in this paper would be ones of the aspects in the whole water and wastewater conditions and management in Thailand. The estimation results of pollutant discharges, pollutant loads, and water quality presented in this paper are partly based on the existing literature. These studies have been conducted mostly in 1970's and 1980's in Thailand. Integration of the research results is considered to be necessary to understand the conditions of whole water and wastewater conditions, which will be also useful for actual water and wastewater management development.

A framework of the research and administrative sectors to address water quality and management are well constructed in Thailand including periodical water quality monitoring in the rivers and canals, dissemination of information to ordinary people (PCD, 2006a,b), multi-functional water pollution control program (Simachaya, 2000; Tsuzuki et al., 2008a), integral water resource management (IWRM), and environmental education programs (Lekphet et al., 2004; Thongnopphakun, 2006). The results of this study showed the possibility of effectiveness of PDCs and PLC $\mathrm{Fb}_{\mathrm{wb}}$ estimations and the scenario-based approach in the existing framework in Thailand.

\section{CONCLUSIONS}

Pollutant discharge and pollutant load indicators were utilized to show the direction of ambient water quality improvement with quantitative analysis framework considering the economic aspect of on-site treatment facilities.

Pollutant discharges from municipal wastewater and pollutant loads in ambient water were estimated in Pak Kret District, peri-urban area of Bangkok, Thailand. Reaching ratios of pollutants from Pak Kret District to $67 \mathrm{~km}$ from river mouth were estimated as $15 \%$ for BOD, $74 \%$ for $\mathrm{TN}$ and $51 \%$ for TP. $\mathrm{PLC}_{\mathrm{wb}}$ were estimated at $67 \mathrm{~km}$ from river mouth as the receiving water as $7.2 \mathrm{~g}-\mathrm{BOD}$ person $^{-1} \mathrm{day}^{-1}, 9.2 \mathrm{~g}$-TN person ${ }^{-1} \mathrm{day}^{-1}$ and $1.2 \mathrm{~g}-\mathrm{P}$ person ${ }^{-1}$ day $^{-1}$. PLC $_{\mathrm{wb}}$ estimation was considered to be more reliable when the nearest section of the river rather than river mouth was considered as receiving water because of the land and river bed flatness. Annual average pollutant contributions of municipal wastewater from Pak Kret District to the river water quality increases were estimated as $0.34 \mathrm{mg}$-BOD $1^{-1}$ day $^{-1}, 0.48 \mathrm{mg}_{-\mathrm{N}{ }^{-1}}$ day $^{-1}$ and $0.066 \mathrm{mg}-\mathrm{P} \mathrm{l}^{-1}$ day $^{-1}$, assuming that discharged pollutants should spread over the $20-\mathrm{km}$ section of the river.

The results of the scenario-based approach showed percentages of water quality improvement in the Chao Phraya River to be $6.4-16 \%$ for BOD, $15-26 \%$ for TN and $14-22 \%$ for TP in the three cases, i.e. by introducing packaged on-site wastewater 
treatment systems without SSL or centralized WWTPs in Pak Kret District.

The PDCs estimation results and the cost benefit comparison results showed the effectiveness of PDCs to evaluate various wastewater treatment systems. PDCs estimation and scenario based approach will enhance sanitation sector activities in the frameworks of academia and administration in developing countries including Thailand to address water quality improvement.

\section{ACKNOWLEDGEMENTS}

This research was financially supported by Japan Education Center for Environmental Sanitation in Japanese Fiscal Year 2006 when the first author was a researcher at Shimane University. River water quality data were obtained from PCD, Thailand. Base map of a part of Figure 1 was prepared by Mr. Edgar Pimiento, GIS master student, Lund University.

\section{REFERENCES}

Apichatvullop, A. (1976). Diffusion process in the Chao Phya estuary, AIT M.Sc. Thesis, Bangkok, Thailand.

Butler, D. and Parkinson, J. (1997). Towards sustainable urban drainage., Water Sci. and Technol., 35 (9), 53-63.

Camp, Dresser and McKee. (1968). Pollution study on the Chao Phya River, Master Plan Report on the Sewerage, Drainage and Flood Protection Systems for Bangkok and Thonburi, Bangkok, Thailand.

Chay, S.C. (1973). Water quality control in the Chao Phraya River estuary, AIT M.Sc. Thesis, Bangkok, Thailand.

Chen, J. and Beck, M. B. (1997). Towards designing sustainable urban wastewater infrastructures: A screening analysis., Water Sci. and Technol., 35 (9), 99-112.

Choguill, C., Fransys, R. and Cotton, A. (1993). Planning for water and sanitation; 1993. cited in UNESCO-WAAP (2003).

Donohue, I., McGarrigle, M.L. and Mills, P. (2006). Linking catchment characteristics and water chemistry with the ecological status of Irish rivers., Water Research, $\mathbf{4 0 ,}$ 91-98.

Dulaiova, H., Burnett, W.C., Wattayakorn, G. and Sojisuporn, P. (2006). Are groundwater inputs into river-dominated areas important? The Chao Phraya River Gulf of Thailand., Limnology and Oceanography, 51 (5), 2232-2247.

Ebise, S. and Kawamura, H. (2008). Frequency of Routine and Flooding-stage Observations for Precise Annual Total Pollutant Loads and their Estimating Method in the Yodo River, J. of Water and Environ. Technol., 6 (2), 93-101.

Fittschen, I. and Niemczynowicz, J. (1997). Experiences with dry sanitation and greywater treatment in the ecovillage Toarp, Sweden., Water Sci. and Technol., 35 (9), 161-170.

Friedler, E. and Butler, D. (1996). Quantifying the inherent uncertainty in the quantity and quality of domestic wastewater., Water Sci. and Technol., 33 (2), 65-78.

Giri, R.R., Takeuchi J. and Ozaki H. (2006). Biodegradation of domestic wastewater under the simulated conditions of Thailand., Water and Environment Journal, 20, 169-176. 
Guo, R. and Yang, K. (2003). Political economy of transnational water pollution: What do the LMB data (1985-2000) say?, Environmental Management, 32 (4), 433-444.

Hanæus, J., Hellström, D. and Johansson, E. (1997). A study of a urine separation system in an ecological village in northern Sweden., Water Sci. and Technol., 35 (9), 153-160.

Harada, H., Matsui, S., Matsuda, T., Shimizu, Y., Utsumi, H., Ono, S., Phi, D.T. and Winblad, U. (2004). Implementation of the project to introduce Ecological Sanitation toilets to a minority hamlet of Vietnam. In: Proceedings of the 12th Symposium of Global Environment, 135-140, Japan Society of Civil Engineers. (in Japanese with English abstract)

Harremoës, P. (1997). Integrated water and waste management., Water Sci. and Technol., 35 (9), 11-20.

Henze, M. (1997). Waste design for households with respect to water, organics and nutrients., Water Sci. and Technol., 35 (9), 113-120.

Hosoi, Y., Kido, Y., Nagira, H., Yoshida H. and Bouda, Y. (1996). Analysis of water pollution and evaluation of purification measures in an urban river basin., Water Sci. and Technol., 34 (12), 33-40.

Ichiki, A., Yamada, K. and Ohnishi, T. (1996). Prediction of runoff pollutant load considering characteristics of the river basin., Water Sci. and Technol., 33 (4-5), 117-126.

Ii, H. and Fujita, K. (2005). River basin water and material cycle. In: Proceedings of River Technology (Kasen Gijutsu Ronbunsyu), 11, 7-12. (in Japanese)

International Steering Committee for Global Mapping (2008). Global Mapping Homepage. (http://www.iscgm.org/cgi-bin/fswiki/wiki.cgi)

Japanese Ministry of the Environment (2001). Environment White Paper 2001 (Heisei 13), 460p. (in Japanese)

Japanese Sewage Works Association (1997). Guidelines for preparing wastewater treatment master plan in the developing countries, Tokyo, 276p. (in Japanese)

Jarusombat, S. and Wajjwalku, S. (2003). The role of Japanese ODA for environmental protection in Thailand after 1992, Research Results of the Sumitomo Foundation Research Projects awarded in Japanese Fiscal Year 2001.

(http://www.sumitomo.or.jp/e/sub/jare01e-rs39.htm)

Jetten, M.S.M., Horn, S.J. and van Loosdrecht, M.C.M. (1997). Towards a more sustainable municipal wastewater treatment system., Water Sci. and Technol., 35 (9), 171-180.

Kasemsan, S. (1970). Pollution Study of the Chao Phya River, 1969-1970., Sanitary Div., Department of Health, Ministry of Public Health, Bangkok, Thailand; 1970. cited in Chay (1973).

Koottatep, T., Kim, O.N.T., Polprasert, C., Heinss, U., Montangero, A. and Strauss, M. (2001). Septage dewatering in vertical-flow constructed wetlands located in the tropics., Water Sci. and Technol., 44 (2-3), 181-188.

Koottatep, T. and Chaosakul, T. (2005). Life cycle assessment of wastewater treatment system in Bangkok City. In: Proceedings of the Third International Symposium on Southeast Asian Water Environment, 111-118.

Kunimatsu, T. and Muraoka, K. (1989). Model analysis of river water pollution., Gihoudou Syuppan, Tokyo, 266p. (in Japanese)

Larsen, T.A. and Gujer, W. (1997). The concept of sustainable urban water management., Water Sci. and Technol., 35 (9), 3-10. 
Lekphet, S., Panichayapichet, P., Suwanchoojit, A., Simachaya, W. and Chuersuwan, N. (2004). Decision Support Model for Integrated Water Resources Management: A case study for the Ta-Chin River, Thailand. In: Proceedings of the $2 n d A P H W$ Conference, Singapore.

Lohani, B.N., Thanh, N.C., Muttamaram, S. and Liengcharernsit. (1980). Mathematical optimization model for regional water quality management, AIT, Thailand.

Ludwig, H.F. and Mohit, K. (2000). Appropriate technology for municipal sewerage/excreta management in developing countries, Thailand case study., The Environmentalists, 20, 215-219.

Mara, D. (1996). Low-cost sewerage, John Wiley \& Sons, 225p.

Mara, D. and Cairncross, S. (1989). Guidelines for the safe use of wastewater and excreta in agriculture and aquaculture, Geneva, World Health Organization.

Marcotullio, P.J. (2007). Urban water-related environmental transitions in Southeast Asia., Sustainability Science, 2 (1), 27-54.

Matsui, S. (2002). The Potential of ecological sanitation., Japan Review of International Affairs, Winter, 303-314.

McIntosh, A.C. (2003). Chapter 10: Sanitation. In: Asian Water Supplies, Reaching the Urban Poor, Asian Development Bank and International Water Association.

Nishimura, K., Watanabe T. and Kiso Y. (2004). Application of life cycle approach for planning of Gappei-shori Johkasou system., Journal of Small Domestic Wastewater Treatment Research (Johkasou Kenkyu), 16, 33-41. (in Japanese with English abstract)

Noyboonya, W. and Hempoonsert, J. (2008). Material flow analysis of phosphorus in the MaeKlong River, MSc Thesis, 88p., Mahidol University, Thailand. (http://mulinet3.li.mahidol.ac.th/e-thesis1/cd418/4736369.pdf) (Accessed in Nov., 2009)

Okumura, S., Yamamoto, Y., Kobayashi, E. and Mutaguchi, K. (2006). Simple improvement of plant and modification of operating method for advanced removal of nitrogen and phosphorus in existing middle scale johkasou., Journal of Small Domestic Wastewater Treatment Research (Johkasou Kenkyu), 18, 58-67. (in Japanese with English abstract)

Ogawa, H. (2006). Summary and treatment characteristics of Community-plants in domestic wastewater treatment systems., Journal of Small Domestic Wastewater Treatment Research (Johkasou Kenkyu), 18, 33-41. (in Japanese with English abstract)

Pescod, M.B. and Ratasak, S. (1968). Oxygen balance in the Cho Phya River estuary. Research Report No.3., Asian Institute of Technology. cited in Chay (1973).

Pollution Control Department (PCD), Thailand. (2006a). Thailand state of the pollution report 2004.

Pollution Control Department (PCD), Thailand. (2006b). Water quality and management. http://www.pcd.go.th/info_serv/en_water_wt.html. (in Thai)

Pollution Control Department (PCD), Thailand. (2006c). River water quality data of the Chao Phraya River.

Polprasert, C. (2007). Water Environment issues of Bangkok City, Thailand: Options for sustainable management., ScienceAsia, 33 Supplement 1, 57-58.

Sarikaya, H.Z., Sevimli, M.F. and Çitil, E. (1999). Region-wide assessment of the land-based sources of pollution of the Black Sea., Water Sci. and Technol., 39 (8), 193-200. 
Schaffner, M. (2007). Applying a material flow analysis model to assess river water pollution and mitigation potentials: A case-study in the Thachin River Basin, Central Thailand, Doctoral Thesis, 232p., Bern University, Germany.

(http://www.zb.unibe.ch/download/eldiss/07schaffner_m.pdf) (Accessed in Nov., 2009)

Schaffner, M., Bader, H.P. and Scheidegger, R. (2009). Modeling the contribution of point sources and non-point sources to Thachin River water pollution., Science of the Total Environment, 207, 4902-4915.

Schreiber, J.D., Rebich, R.A. and Cooper, C.M. (2001). Dynamics of Diffuse Pollution from US Southern Watersheds., Water Research, 35 (10), 2534-2542.

Sinsupan, T. (2004). Material flux analysis (MFA) for planning of domestic wastes and wastewater management: case study in Pak Kret Municipality, Nonthaburi, Thailand., AIT M.Sc. Thesis, Bangkok, Thailand.

Simachaya, W. (2000). Water quality management in Thailand., In: Proceedings of Workshop on "Environmentally sound technology on water quality management", UNEP, Mekong River Commission.

Smet, J. and Sugden, S. (2006). Ecological Sanitation, Well Factsheet (http://info.lut.ac.uk/well/resources/fact-sheets/fact-sheets-htm/Ecological\%20sanita tion.htm)

Smith, R.S. (2001). Sanitation: Controlling problems at source, Water, Sanitation and Health, WHO. (http://www.who.int/water_sanitation_health/sanitproblems /en/index4.html)

Stutter, M.I., Langan, S.J. and Demars, B.O.L. (2007). River sediments provide a link between catchment pressures and ecological status in a mixed land use Scottish River system, Water Research, 41 (12), 2803-2815.

Sugimoto, Y., Komai, Y. and Kunimatsu, T. (2008). Evaluation of loading rate of nitrogen from rice-paddies by small watershed method, J. of Water and Environ. Technol., 6 (2), 113-126.

Suharyanto and Matsushita, J. (2009) Comparative study on integrated wastewater management system model for developing countries under rapid urbanization. In: The Seventh International Symposium on Southeast Asian Water Environment, Bangkok, Thailand.

Takeda, I., and Fukushima A. (2004). Phosphorus purification in a paddy field watershed using a circular irrigation system and the role of iron compounds., Water Research, 38, 4065-4074.

Takeda, I. and Fukushima A. (2006). Long-term changes in pollutant load outflows and purification function in a paddy field watershed using a circular irrigation system., Water Research, 40, 569-578.

Thapinta, A., Utarasakul, T. and Thapinta, S. (2008). Current Status on Non-point Source Pollution from Agriculture in Thailand, 46p., The Thailand Research Fund Bangkok, Thailand.

(http://www.trf.or.th/TRFGallery/Upload/Gallery/Documents/Files/1000000005.pdf) (Accessed in Nov., 2009)

Thongnopphakun, D. (2006). We love Thachin Club, International symposium on community activities for the conservation of water environment - lessons learned from community activities. In: Oral Presentation Proceedings of International Symposium on Community Activities for the Conservation of Water Environment, Bangkok, Thailand. 
Tsuzuki, Y. (2004). Proposal of environmental accounting housekeeping (EAH) books of domestic wastewater based on water pollutant loads per capita: A case study of Sanbanze Tidal Coastal Zone, Tokyo Bay., Journal of Global Environment Engineering, 10, 187-196.

Tsuzuki, Y. (2005). Domestic wastewater treatment in the drainage areas of Lakes Shinji and Nakaumi: Treatment efficiency and dissemination for ordinary citizens., $L A G U N A, 12,53-61$. (in Japanese with English abstract)

Tsuzuki, Y. (2006a). An index directly indicates land-based pollutant load contributions of domestic wastewater to the water pollution and its application., Science of the Total Environment, 370, 425-440.

Tsuzuki, Y. (2006b). Complicated aspects of water pollutant discharges per capita (PDC). In: Poster Presentation Proceedings of the 4th International Symposium on Southeast Asian Water Environment, Dec. 6-8, 2006, Bangkok, Thailand, 61-68.

Tsuzuki, Y. (2007). Relationships between pollutant discharges per capita (PDC) of domestic wastewater and the economic development indicators., Journal of Environmental Systems and Engineering, Japan Society of Civil Engineers, 63 (4), 224-232 (Dobuku Gakkai Ronbunsyu, Category G) (in Japanese with English abstract)

Tsuzuki, Y. (2008). Relationships between water pollutant discharges per capita (PDCs) and indicators of economic level, water supply and sanitation in developing countries., Ecological Economics, 68, 273-287.

Tsuzuki, Y. (2009a). Onsite sanitation in Thailand., Journal of Small Domestic Wastewater Treatment Systems (Gekkan Johkasou), No. 393, 37-40 (in Japanese)

Tsuzuki, Y. (2009b). Comparison of pollutant discharges per capita (PDC) and its relationships with economic development: An indicator for ambient water quality improvement as well as the Millennium Development Goals (MDGs) sanitation indicator., Ecological Indicator, 9, 971-981.

Tsuzuki, Y. and Koottatep, T. (2008). Toward sustainable wastewater treatment systems in urban and peri-urban area of developing countries: a case study in Bangkok, Thailand. In: Proceedings CD-ROM of 8th IWA specialized Conference on Small Water and Wastewater Systems and 2nd specialized Conference on Decentralized Water and Wastewater International Network, February 6 9, 2008, Coimbatore, India.

Tsuzuki Y., Koottatep, T. and Rahman, M.M. (2007a). Pollutant discharge and pollutant load in the tidal area of the rivers in the developing countries: Survey results in the autumn and winter in 2006 and desirable direction for water quality improvement. In: Proceedings of the 15th Symposium of Global Environment, Japan Society of Civil Engineers, 95-100.

Tsuzuki Y., Koottatep, T., Rahman, M.M. and Ahmed, F. (2007b). Preliminary study on pollutant discharge from domestic wastewater and pollutant load in the river: a comparative study between Japan, Thailand and Bangladesh., In: Oral presentation proceedings of International forum on Water Environmental Governance in Asia, 14-15 March 2007, Bangkok, Thailand, 107-112.

Tsuzuki Y., Koottatep, T., Rahman, M.M. and Ahamed, F. (2008a). Pollutant discharges from domestic wastewater and pollutant loads in the rivers in the developing countries: fields survey and data collection in 2006., Journal of Small Domestic Wastewater Treatment Research (Joukasou Kenkyu), 20 (1), 1-13. (in Japanese with English abstract) 
Tsuzuki Y., Koottatep, T., Rahman, MD M. and Ahamed, F. (2008b). Pollutant discharge and pollutant load in the tidal area of the ambient water bodies in developing countries: Survey results in autumn and winter in 2006., Journal of Global Environment Engineering, 13, 121-133.

Tsuzuki, Y., Koottatep, T., Wattanachira, S., Sarathai, Y. and Wongburana, C. (2009). On-site treatment in the wastewater treatment plants (WWTPs) areas in Thailand., Journal of Global Environment Engineering, 14, 57-65.

Ujang, Z. and Buckley, C. (2002). Water and wastewater in developing countries: present reality and strategy for the future., Water Sci. and Technol., 46 (9), 1-9.

United Nations. (2007). United Nations site for the MDG Indicators. (http://mdgs.un.org/unsd/ mdg/Default.aspx).

United Nations Development Programme (UNDP). (2006). Asia-Pacific Human Development Report 2006. Original source is UNSTATS website (http://unstats.un.org/unsd/mi/mi_goals.asp, World Bank, 2005).

United Nations Education, Scientific and Cultural Organization, and United Nations Water Assessment Programme (UNESCO-WWAP). (2003). Water for people, water for life., United Nations Water Development Report, UNESCO Publishing and Berghahan Books, Barcelona.

United Nations Secretary-General's Advisory Board on Water and Sanitation. (2006). Hashimoto Action Plan, Compendium of Actions.

Wakida, F.T. and Lerner, D.N. (2005). Non-agricultural sources of groundwater nitrate: A review and case study., Water Research, 39, 3-16.

Water Environment Partnership in Asia (WEPA). (2007). Database of technologies in operation. (http://www.wepa-db.net/technologies/top.htm).

Working Group of the Office of Natural Water Resources Committee (ONWRC) of Thailand. (2003). Chao Phraya River Basin, Thailand. In: Water for people, water for life, UNESCO-WWAP, pp.387-400.

World Bank. (2001). Thailand Environment Monitor 2000.

Yu, H., Tay, J.-H. and Wilson, F. (1997). A sustainable municipal wastewater treatment process for tropical and subtropical regions in developing countries., Water Sci. and Technol., 35 (9), 191-198. 